九州大学学術情報リポジトリ

Kyushu University Institutional Repository

\title{
A Regularly Interstratified \\ Chlorite/Vermiculite in a Talc-Chlorite Vein
}

Nakamuta, Yoshihiro

Faculty of Science, Kyushu University

https://doi.org/10.5109/1546080

出版情報：九州大學理學部紀要：Series D, Geology. 24 (4)，pp.253-279，1981-12-25. Faculty of Science, Kyushu University バージョン：

権利関係 : 
Mem. Fac. Sci., Kyushu Univ., Ser. D, Geol., Vol. XXIV, No. 4, pp. 253-279, text-figs. $1-12$, tables 1-8, plate 18 , December 25,1981

\title{
A Regularly Interstratified Chlorite/Vermiculite in a Talc-Chlorite Vein
}

\author{
Yoshihiro NAKAMUTA
}

\begin{abstract}
A regularly interstratified chlorite/vermiculite was found at the surface of an outcrop of talc-chlorite vein which developed in a serpentinite body at Torika, Saipi-Cho, Nagasaki Prefecture, Japan. The regularly interstratified chlorite/vermiculite, which is regarded as a weathering product of $\mathrm{Al}$-poor $\mathrm{Mg}$ chlorite with II $b$ polytype on the basis of its mode of occurrence, was investigated by x-ray, chemical, infrared and thermal methods together with the parent chlorite.

The regularly interstratified chlorite/vermiculite forms an intimate mixture with chlorite in varying proportions, and seems to be a relatively stable intermediate phase in the weathering process of chlorite. The chemical and $\mathrm{x}$-ray properties of the regularly interstratified chlorite/vermiculite suggest the preferential removal of alternate hydroxide sheets of chlorite during the weathering process.

The regularly interstratified chlorite/vermiculite gives $h k l$ reflections, which have been indexed in terms of an orthohexagonal cell $(a=5.34, b=9.25$, $c=28.8 \AA$ ). The $20 l$ intensities are interpreted as a stacking sequence composed of I $a$ vermiculite and II $b$ chlorite layer types.
\end{abstract}

\section{Introduction}

Chlorites are common constituents of many metamorphic and sedimentary rocks. In studies of soils developing on these rocks, mineralogical changes of chlorites by weathering have been investigated together with the weathering of other minerals (Droste, 1956; Harrison and MURRaY, 1959; Droste et al., 1962 ; Millot and CAMEZ, 1963; JACKson, 1963; BAYliss and LoughnAN, 1964). These investigations indicate that chlorites change by weathering to interstratified minerals of chlorite and expandable layers. JoHNSON (1964) investigated mainly by the x-ray method an interstratified mineral formed by the weathering of chlorite in a Highfield channery silt loam soil profile in Adams Country, Pennsylvania. He showed that the mineral was a regularly interstratified chlorite/vermiculite, and hypothesized a preferential removal of alternate brucite interlayers of chlorite in a leaching environment. Post and JANKE (1974) and HARBILLON and MAKUMBI (1975) also suggested the formation of regularly interstratified chlorite/vermiculite in the weathering process of chlorite. However, details of the mineralogical properties of the interstratified minerals

Manuscript received July 2, 1981. 
formed in the weathering process of chlorite have not hitherto been available.

The writer found that a part of the coarse-grained chlorite, Al-poor Mgchlorite with IIb polytype, in a talc-chlorite vein at Torika, in the Nishisonogi Peninsula in the northwest of Kyushu Island, Japan, was altered by weathering into a regularly interstratified chlorite/vermiculite. In this study, the interstratified mineral is investigated in detail by $\mathrm{x}$-ray, chemical, infrared and thermal analyses, and it is found that the chemical and x-ray properties of the mineral suggest the preferential removal of the alternate hydroxide sheets of chlorite during the weathering process, and that the mineral has a kind of three dimensional regularity of a type similar to the semirandom stacking of BROWN and BAILEY (1962).

\section{Locality and Mode of Occurrence of the Talc-Chlorite Vein}

In the Nishisonogi Peninsula, in the northwest of Kyushu Island, Japan, metamorphic rocks composed mainly of graphite-quartz-muscovite schist and a small amount of greenschist are widely distributed. Serpentinite bodies have intruded in the metamorphic rocks, and they are distributed mainly along the axis and wings of the Nishisonogi anticline (NODA and MUTA, 1957), which lies on a NNE-SSW axis.

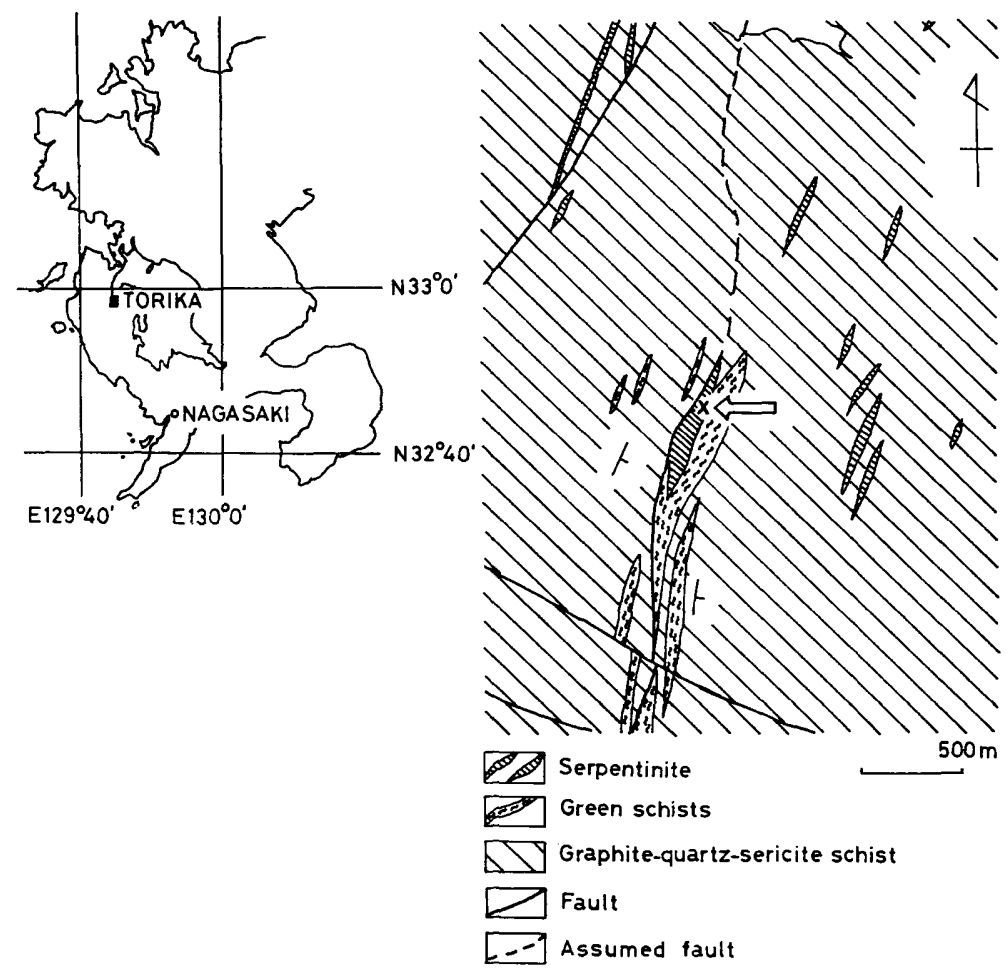

Fig. 1. Locality map of the talc-chlorite vein. 


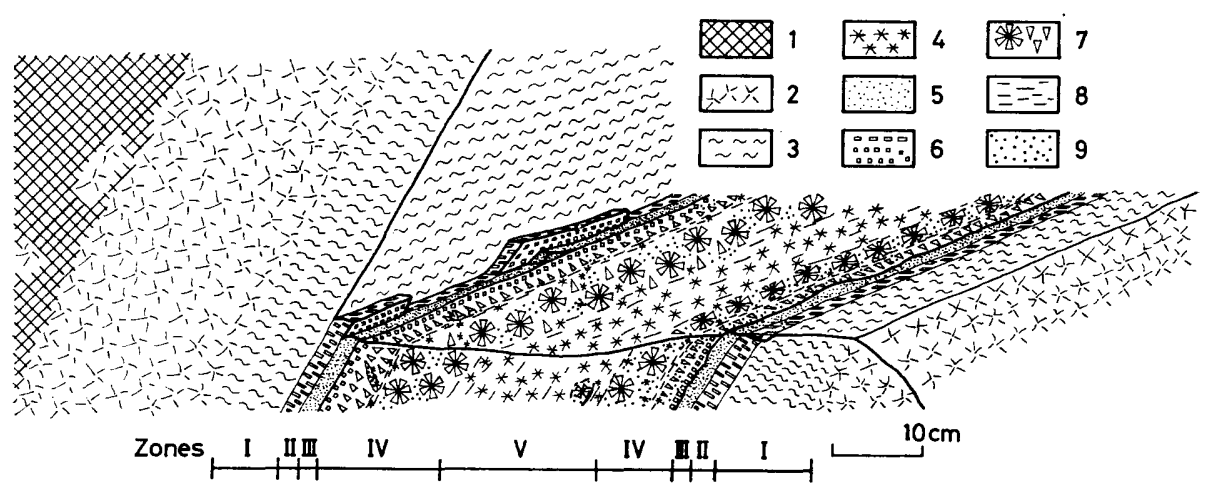

Fig. 2. Schematic diagram of the talc-chlorite vein.

1: serpentinite.

3: fibrous talc.

5: fibrous chlorite.

7: radiated scaly chlorite.

9: fine-grained granular chlorite together with talc.
2: fine-grained scaly talc.

4: coarse-grained scaly talc.

6: scaly chlorite.

8: foliated chlorite.

A talc-chlorite vein has developed in a serpentinite body at Torika, Saipi-cho, Nagasaki Prefecture. The locality of the talc-chlorite vein is shown in Fig. 1. The talc-chlorite vein strikes $\mathrm{N} 30^{\circ} \mathrm{W}$ and dips $60^{\circ} \mathrm{W}$. The width of the vein is about $65 \mathrm{~cm}$. It is mainly composed of talc and chlorite with small amounts of magnetite and carbonate minerals, and these minerals occur in symmetrical and zonal arrangement. The boundaries of each zone are sharp and clear. Therefore, the talc-chlorite vein was conveniently divided into five zones based on the mineral assemblage and the habit of chlorite. A schematic diagram of the vein is shown in Fig. 2. The zonal arrangement of minerals from the side of wall rock to the center of the vein is as follows:

Zone I: fibrous talc with small amounts of magnetite and carbonate minerals (10-15 cm width).

Zone II: scaly chlorite $(2 \mathrm{~cm}$ width).

Zone III: fine-grained fibrous chlorite $(2-10 \mathrm{~cm}$ width).

Zone IV: scaly chlorite and coarse-grained radiated chlorite with granular chlorite and talc $(10 \mathrm{~cm}$ width).

Zone V: talc with foliated chlorite arranged approximately parallel to the wall rock $(5-10 \mathrm{~cm}$ width).

In the zones from fibrous talc (Zone I) to fibrous chlorite (Zone II), a distinct schistosity perpendicular or oblique to the wall rock of the vein is observable. On either side of fibrous talc, scaly talc occurs in serpentinite and forms a transitional zone about $30 \mathrm{~cm}$ wide between the vein and serpentinite body.

The surface of the outcrop of the vein is contaminated by a brown colloidal material, and most of the chlorite flakes on the surface, except at the foot of the overhanging wall shown in Fig. 2, have changed from green to yellowish green or brownish yellow in color. Judging from their modes of occurrence, the change of their color at the surface of the vein is most likely caused by 
Table 1. Macroscopic features and optical properties of chlorites in a talc-chlorite vein.

\begin{tabular}{|c|c|c|c|c|c|c|c|c|}
\hline Zone & Habit & Color & Luster & $\begin{array}{c}\text { Average } \\
\text { grain size }(\mathrm{mm})\end{array}$ & $\begin{array}{l}\text { Optical angle } \\
\text { and (sign) }\end{array}$ & Pleochroism & $\begin{array}{l}\text { Interference } \\
\text { color }\end{array}$ & $\beta$ \\
\hline II & scaly & $\underset{\text { green }}{\text { emerald }}$ & vitreous & $1-2$ & $\begin{array}{l}\text { very small } \\
(-)\end{array}$ & $\begin{array}{l}\mathrm{X} \text { : pale brownish yellow } \\
\mathrm{Y}, \mathrm{Z} \text { : pale green }\end{array}$ & ultra blue & $1.588_{2}$ \\
\hline III & fibrous & green & earthy & $0.05-0.1$ & $\underset{(+)}{\text { small }}$ & $\begin{array}{l}\mathrm{X} \text { : brownish yellow } \\
\mathrm{Y}, \mathrm{Z} \text { : green }\end{array}$ & $\begin{array}{l}\text { pale yellow } \\
\text { to colorless }\end{array}$ & $1.59_{1}$ \\
\hline \multirow{3}{*}{ IV } & scaly & $\underset{\text { green }}{\text { emerald }}$ & vitreous & $1-3$ & $\begin{array}{l}\text { very small } \\
\qquad(-)\end{array}$ & $\begin{array}{l}\mathrm{X} \text { : pale brownish yellow } \\
\mathrm{Y}, \mathrm{Z} \text { : pale green }\end{array}$ & ultra blue & $1.58_{3}$ \\
\hline & $\begin{array}{l}\text { radiated } \\
\text { scaly }\end{array}$ & $\underset{\text { green }}{\text { emerald }}$ & vitreous & $5-10$ & $\begin{array}{l}\text { very small } \\
\qquad(-)\end{array}$ & $\begin{array}{l}\mathrm{X} \text { : pale brownish yellow } \\
\mathrm{Y}, \mathrm{Z} \text { : pale green }\end{array}$ & ultra blue & $1.58_{3}$ \\
\hline & granular & $\begin{array}{l}\text { emerald } \\
\text { green }\end{array}$ & vitreous & 1 & $\begin{array}{l}\text { very small } \\
(+)\end{array}$ & $\begin{array}{l}\mathrm{X}, \mathrm{Y} \text { : pale green } \\
\mathrm{Z} \text { : pale brownish yellow }\end{array}$ & buff yellow & $1.58_{3}$ \\
\hline $\mathrm{V}$ & foliated & $\underset{\text { green }}{\text { emerald }}$ & vitreous & $5-15$ & $\begin{array}{l}\text { very small } \\
\qquad(+)\end{array}$ & $\begin{array}{l}\mathrm{X}, \mathrm{Y} \text { : pale green } \\
\mathrm{Z}: \text { pale brownish yellow }\end{array}$ & buffyellow & $1.58_{5}$ \\
\hline
\end{tabular}


weathering. These yellowish green or brownish yellow flakes contain the regularly interstratified chlorite/vermiculite described below.

\section{Chlorite in a Talc-Chlorite Vein and Weathering Products}

\section{Mineralogical Properties of Chlorite}

As mentioned above, the chlorite in the vein shows various macroscopic features. The features of the fresh green chlorites in each zone are listed in Table 1 together with their optical properties. All chlorites in the vein have small optical angles, but their optical signs vary. Optically negative ones, i.e., scaly chlorites in Zones II and IV and radiated scaly chlorite in Zone IV, show an abnormal interference color of ultra blue and have refractive indices $(\beta)$ of about 1.58. Their optical properties agree with those of minus penninite

Table 2. X-ray powder data and cell dimensions for typical chlorites in talc-chlorite vein.

\begin{tabular}{|c|c|c|c|c|c|c|c|c|c|c|}
\hline & \multicolumn{2}{|c|}{1} & \multicolumn{2}{|c|}{2} & \multicolumn{2}{|c|}{3} & \multicolumn{2}{|c|}{4} & \multicolumn{2}{|l|}{5} \\
\hline$h k l$ & $d(\AA)$ & I & $d(\AA)$ & I & $d(\AA)$ & I & $d(\AA)$ & I & $d(\dot{\mathrm{A}})$ & I \\
\hline $20 \overline{2}$ & 2.59 & 6 & 2.59 & 7 & 2.59 & $5 \frac{1}{2}$ & 2.59 & 5 & 2.59 & 5 \\
\hline 201 & 2.546 & 10 & 2.546 & 10 & 2.544 & 9 & 2.547 & 9 & 2.54 & 8 \\
\hline $20 \overline{3}$ & 2.442 & 10 & 2.447 & $9 \frac{1}{2}$ & 2.444 & $8 \frac{1}{2}$ & 2.447 & $8 \frac{1}{2}$ & 2.44 & 7 \\
\hline 202 & 2.386 & $4 \frac{1}{2}$ & 2.388 & 5 & 2.387 & $4 \frac{1}{2}$ & 2.387 & $4 \frac{1}{2}$ & 2.38 & 4 \\
\hline $20 \overline{4}$ & 2.26 & $4 \frac{1}{2}$ & 2.265 & 4 & 2.265 & 4 & 2.264 & 4 & 2.255 & 4 \\
\hline $\left.\begin{array}{l}20 \overline{5} \\
007\end{array}\right)$ & 2.05 & 6 & 2.04 & 2 & 2.04 & 2 & 2.04 & $2 \frac{1}{2}$ & 2.06 & $1 \frac{1}{2}$ \\
\hline 204 & 2.010 & $8 \frac{1}{2}$ & 2.009 & 9 & 2.011 & 10 & 2.010 & 10 & 2.00 & 6 \\
\hline $20 \overline{6}$ & 1.89 & $1 \frac{1}{2}$ & 1.89 & 3 & 1.89 & 2 & 1.89 & 3 & 1.88 & $2 \frac{1}{2}$ \\
\hline 205 & 1.83 & $1 \frac{1}{2}$ & 1.83 & $2 \frac{1}{2}$ & 1.83 & $2 \frac{1}{2}$ & 1.83 & $2 \frac{1}{2}$ & 1.82 & $2 \frac{1}{2}$ \\
\hline $15 ; 24 ; 31$ & - & & - & & - & & - & & 1.74 & 1 \\
\hline 207 & - & & - & & - & & - & & 1.715 & $\frac{1}{2}$ \\
\hline 206 & - & & 1.66 & $1 \frac{1}{2}$ & 1.67 & 1 & 1.67 & 2 & 1.66 & $1 \frac{1}{2}$ \\
\hline $\left.\begin{array}{l}009 \\
208\end{array}\right)$ & 1.574 & 6 & 1.572 & $6 \frac{1}{2}$ & 1.577 & $5 \frac{1}{2}$ & 1.575 & $6 \frac{1}{2}$ & 1.565 & 3 \\
\hline 060 & 1.540 & $7 \frac{1}{2}$ & 1.541 & 6 & 1.541 & 5 & 1. 541 & 5 & 1.538 & 7 \\
\hline$d(001)$ & 14.3 & & 14.2 & & 14.3 & & 14.3 & & & \\
\hline$b_{0}$ & 9.2 & & 9.2 & & 9.2 & & 9.2 & & & \\
\hline
\end{tabular}

1: fine-grained scaly chlorite in Zone III. 2: fibrous chlorite in Zone III. 3: radiated scaly chlorite in Zone IV. 4: fine-grained granular chlorite in Zone IV. 5: IIb chlorite, Buck Creek, North Carolina (BRown and BAILEY, 1962). 


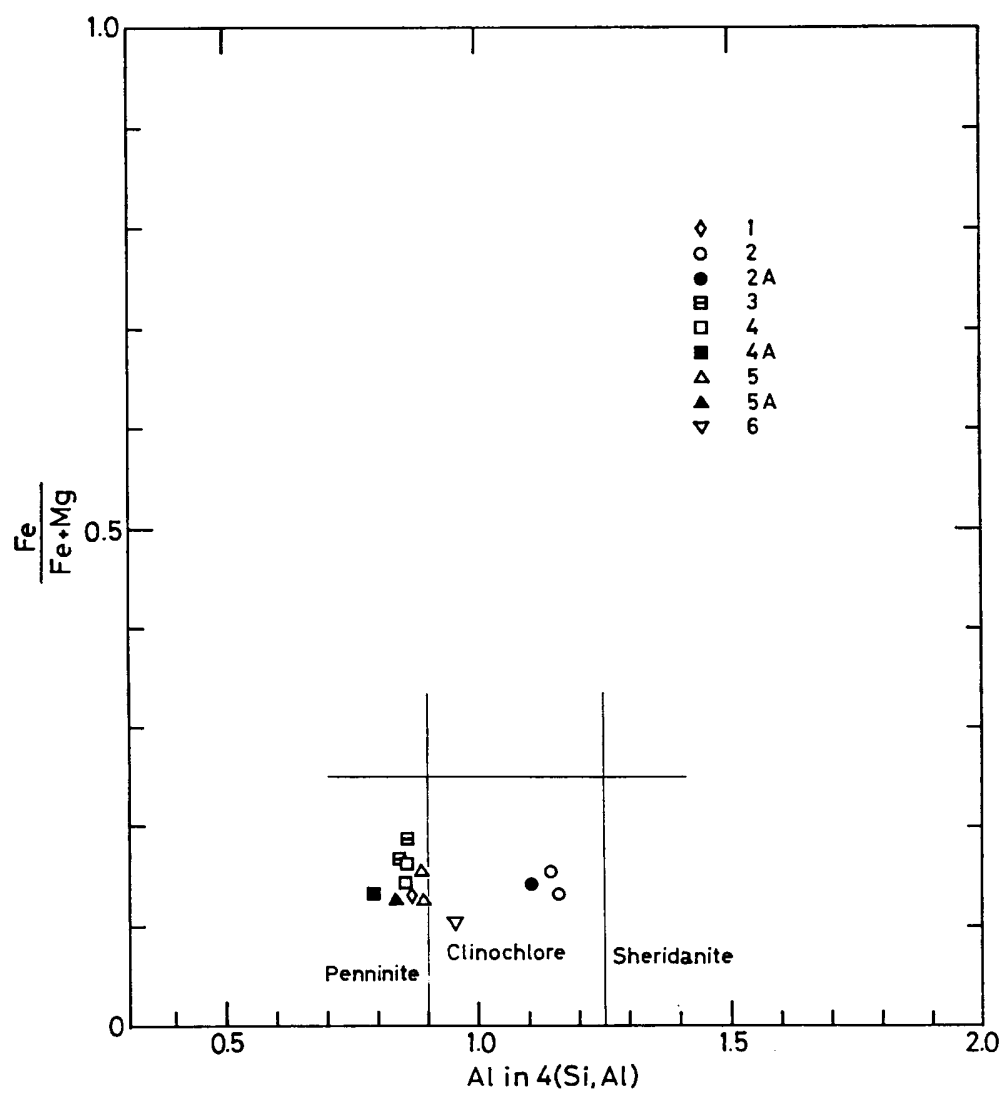

Fig. 3. Chemical compositions of chlorites in talc-chlorite vein.

1: scaly chlorite in Zone II.

2: fibrous chlorite in Zone III.

3: scaly chlorite in Zone IV.

4: radiated scaly chlorite in Zone IV.

5: granular chlorite in Zone IV.

6: foliated chlorite in Zone $\mathrm{V}$.

A: chemical composition analysed by EPMA.

as studied by WINCHeLl (1951). Fibrous chlorite in Zone III, granular chlorite in Zone IV and foliated chlorite in Zone $\mathrm{V}$ are optically positive, but the first chlorite differs from the latter two in the interference color and value of $\beta$. The fibrous chlorite in Zone III shows an interference color of pale yellow to colorless and a refractive index $(\beta)$ of about 1.59 , and corresponds to clinochlore. The latter two show an abnormal interference color of buff yellow and a refractive index $(\beta)$ of about 1.58, and correspond to plus penninite or clinochlore.

$\mathrm{X}$-ray powder patterns of the chlorites were obtained by a diffractometer, using $\mathrm{CuK} \alpha$ radiation. The $b$ dimensions and basal spacings of the chlorites were determined by measuring the 060 spacing and 0012 and 0014 spacings. Silicon was used as an internal standard for the measuring. The x-ray powder data for typical chlorites in the vein are shown in Table 2 together with the 
Table 3. Chemical compositions of typical chlorites and calculation of ions in structural unit.

\begin{tabular}{|c|c|c|c|c|}
\hline \multicolumn{2}{|c|}{ Sample } & 1 & 2 & 3 \\
\hline & $\mathrm{SiO}_{2}$ & 29.49 & 32.32 & 32.16 \\
\hline & $\mathrm{Al}_{2} \mathrm{O}_{3}$ & 17.75 & 13.51 & 14.31 \\
\hline & $\mathrm{FeO}$ & 8.48 & 8.32 & 7.94 \\
\hline & $\mathrm{MgO}$ & 30.09 & 30.68 & 31.00 \\
\hline & Total & $\overline{85.81}$ & $\overline{84.83}$ & $\overline{85.41}$ \\
\hline \multirow{2}{*}{ Tetrahedral } & $\mathrm{Si}$ & 2.90 & 3.20 & 3.16 \\
\hline & Al & 1.10 & 0.80 & 0.84 \\
\hline \multirow{4}{*}{ Octahedral } & $\mathrm{Al}$ & 0.96 & 0.78 & 0.84 \\
\hline & $\mathbf{F e}$ & 0.70 & 0.69 & 0.66 \\
\hline & $\mathbf{M g}$ & 4.41 & 4.53 & 4.54 \\
\hline & Total & $\overline{6.07}$ & $\overline{6.00}$ & $\overline{6.04}$ \\
\hline & 0 & 10 & 10 & 10 \\
\hline & $\mathrm{OH}$ & 8 & 8 & 8 \\
\hline
\end{tabular}

1: fine-grained fibrous chlorite from Zone III. 2: radiated scaly chlorite from Zone IV. 3: fine-grained granular chlorite from Zone IV. Ions in structural unit are calculated on the basis of $\mathrm{O}_{10}(\mathrm{OH})_{8}$.

values of cell dimensions $(d(001)$ and $b)$. The powder data for each chlorite agree with those for II $b$ (monoclinic) polytype (BRown and BAILEY, 1962). As to the cell dimensions, the $b$ values of all chlorites in the vein are similar, but the $d(001)$ values are somewhat variable; that of the fine-grained fibrous chlorite in Zone III is distinctly smaller than those of the other chlorites.

It is well known that the cell dimensions $(d(001)$ and $b)$ and refractive index $(\beta)$ of orthochlorite are intimately related with its chemical composition, i.e., the $d(001)$ value depends on the number of tetrahedral $\mathrm{Al}$ ions, and the $b$ value and refractive index $(\beta)$ on the $\mathrm{Fe}$ atoms in the structure (SHIROZU, $1958,1960)$. The chemical compositions of the chlorites in the vein were determined with $d(001)-b$ and $d(001)-\beta$ diagrams devised by SHIRozU (1960). The results were plotted on a chemical diagram together with the data analysed by EPMA (Fig. 3). The data obtained by EPMA are shown also in Table 3. The $\mathrm{Fe} /(\mathrm{Mg}+\mathrm{Fe})$ ratios of all the chlorites are similar, in the range from 0.1 to 0.2 , but the number of tetrahedral Al ions vary. Most of the fine-grained fibrous chlorite in Zone III contains a larger number of tetrahedral Al ions than the other chlorites. The chlorites in Zones II and IV contain a similar number of tetrahedral $\mathrm{Al}$ ions, in the range from 0.8 to 0.9 . However, the finegrained granular chlorite in Zone IV contains a slightly larger number of tetrahedral Al ions than the scaly chlorite in Zones II and IV. This slight difference in the number of tetrahedral $\mathrm{Al}$ ions between the fine-grained granular chlorite in Zone IV and the scaly chlorites in Zones II and IV is indicated also by their optical signs; Al-poor penninite is optically negative, while the 
Al-rich type is positive (WINCHeLL, 1951). Foliated chlorite in Zone V contains a slightly larger number of tetrahedral $\mathrm{Al}$ ions than the chlorites in Zones II and IV.

The results of optical and x-ray investigations of the chlorites in the talcchlorite vein reveal that all the chlorites are Mg-rich ones with II $b$ polytype, although the $\mathrm{Al}$ content varies with the zone in which they occur and with their habits.

\section{Weathering Products of Chlorite}

The chlorite flakes of which the color has been changed from green to yellowish green or brownish yellow are found at the surface of the outcrop of the vein. The surface is contaminated by brown colloidal material, which gives the x-ray powder pattern of goethite. The chlorites of all the zones of the vein show similar change of their color at the surface of the outcrop. But, the amounts of the altered chlorites vary within the surface of the outcrop. The chlorite which is in the side of the wall rock overhanging the vein is relatively fresh. In Zones II and III, which consist of compact aggregates of fine-grained chlorites, altered chlorites form very thin crust covering the surface. The alteration is extensive in Zone IV, in which coarse-grained chlorite flakes form loose aggregate together with talc. In this study, yellowish green (sample C) and brownish yellow (sample D) flakes were collected from Zone IV together with two fresh green chlorite samples (samples A and B). The edge of sample A has been altered partially and shows an appearance similar to that of sample C. Samples A and C are coarse-grained and scaly, whereas samples $\mathrm{B}$ and $\mathrm{D}$ are fine-grained and granular. As mentioned above, both chlorites are $\mathrm{Al}$-poor $\mathrm{Mg}$-chlorite with II $b$ polytype. The microphotographs of these chlorite flakes are shown in Plate 18.

Optically, the yellowish green flake (sample C) shows a yellow interference color, differing from that of the fresh green chlorite (sample A) which shows the abnormal interference color of ultra blue. The brownish yellow flake (sample D) has an appearance extremely different from that of the fresh green chlorite (sample B) under the microscope, i.e., it has irregularly curved cleavage, and many cracks, and shows no interference color. The refractive indices $(\beta)$ of the yellowish green and brownish yellow flakes, measured by the immersion

\section{Explanation of Plate 18}

Microphotographs under crossed polars of samples A, B, C and D. In each photograph, points analysed by EPMA are shown.

A. Sample A (green flake), having coarse-grained radiated scaly form. The edge of the flake has been altered partially and shows an appearance similar to that of sample C.

B. Sample B (green flake), having granular form.

C. Sample C (yellowish green flake), having coarse-grained scaly form.

D. Sample D (brownish yellow flake), having granular form. 

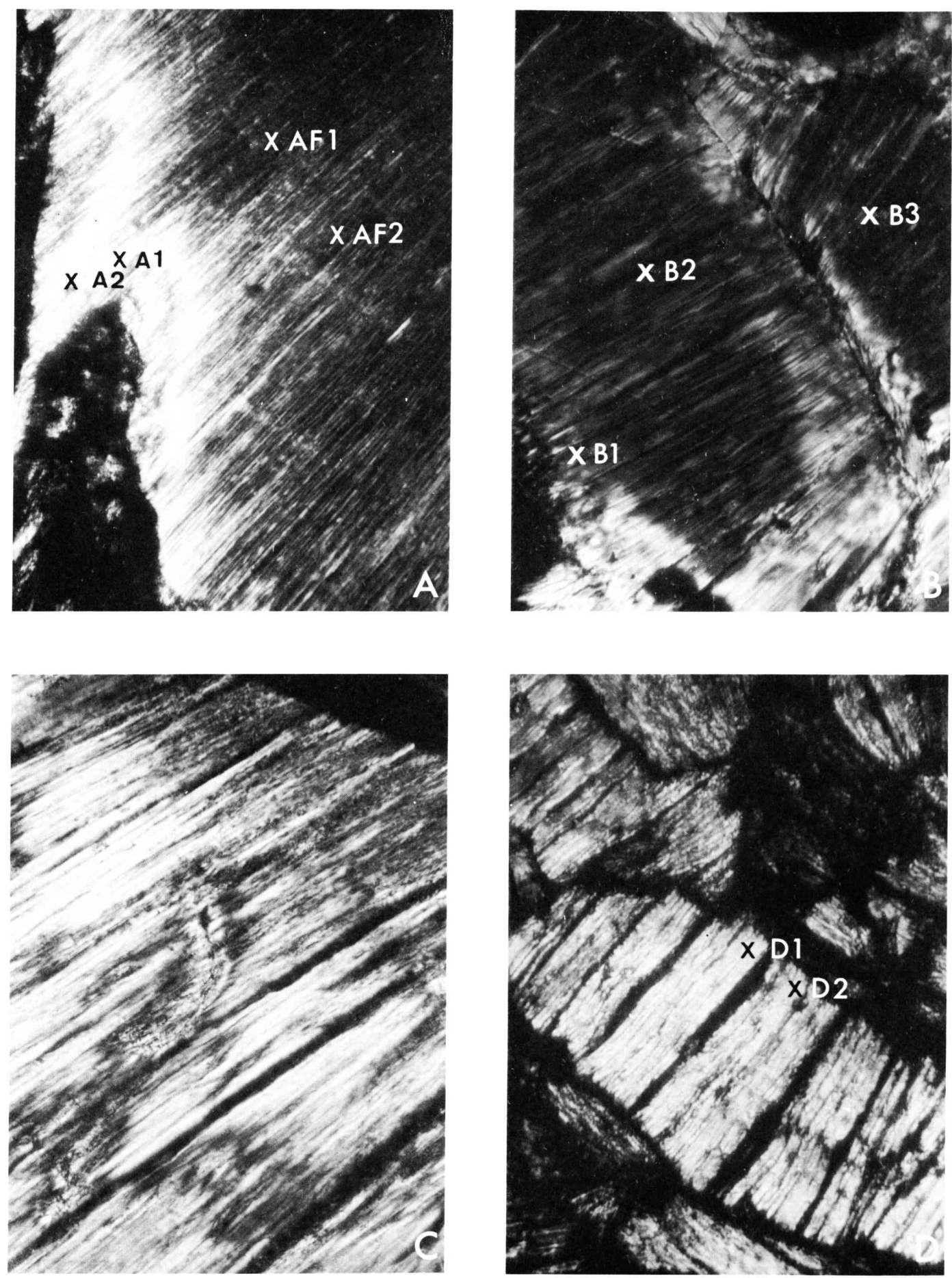

\section{$0.1 \mathrm{~mm}$}

Y. NAKAmUta: Regularly Interstratified Chlorite/Vermiculite 


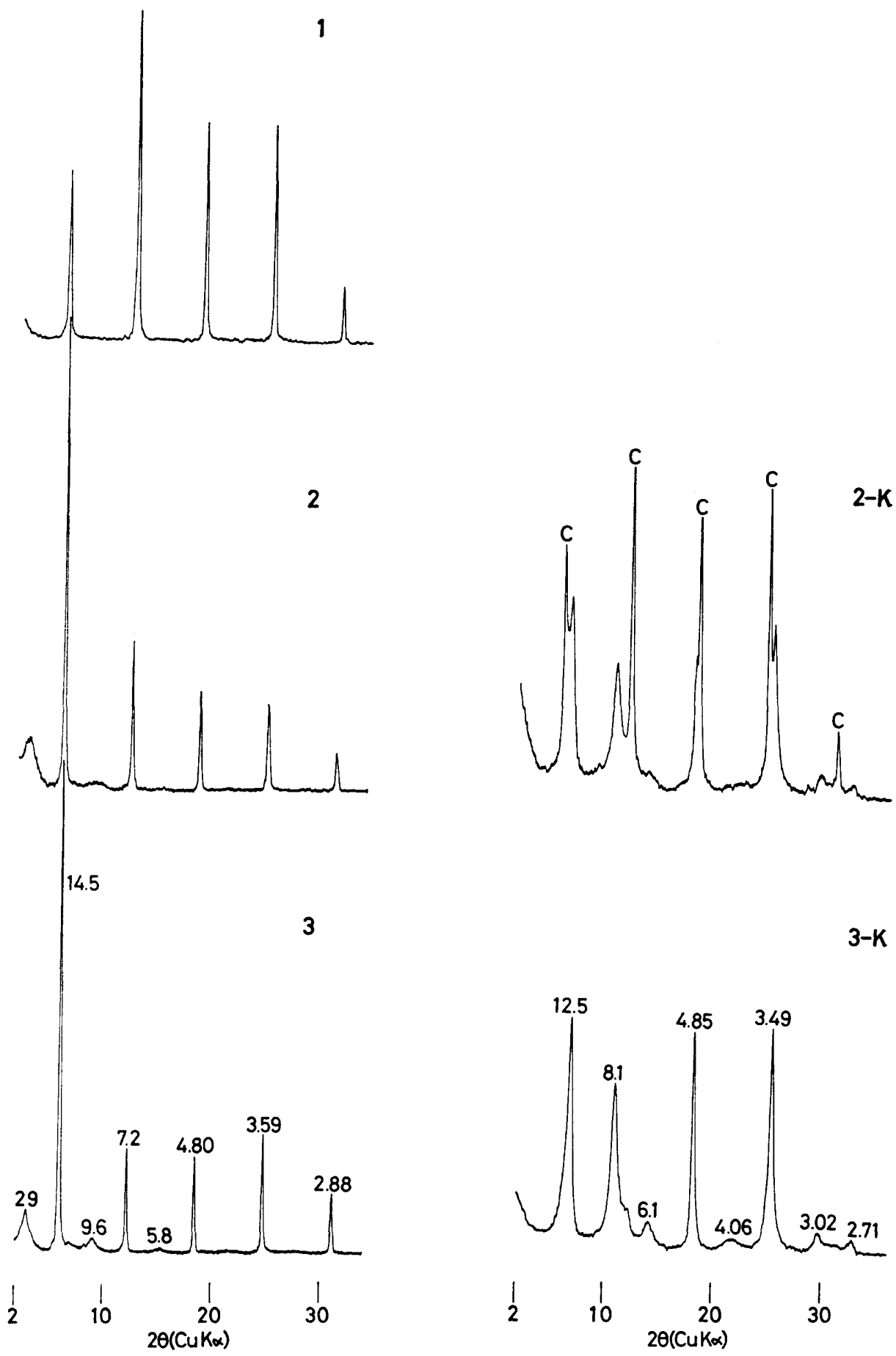

Fig. 4. X-ray patterns of green, yellowish green and brownish yellow flakes.

1: sample $B$. 2: sample C. 3: sample $D$.

$\mathrm{K}$ : after K-saturation. C: chlorite. 
method, are lower than those of the fresh green chlorites which have a $\beta$ of about 1.58. The refractive index $(\beta)$ of the brownish yellow flake is $1.56_{5}-1.57_{0}$.

$\mathrm{X}$-ray patterns of the yellowish green (sample $C$ ) and brownish yellow (sample D) flakes are shown in Fig. 4, along with that of fresh green chlorite (sample B). In Fig. 4, the patterns of $\mathrm{K}$-saturated materials, prepared by washing powdered material with $1 \mathrm{~N} \mathrm{KCH}_{3} \mathrm{COOH}$, are also shown.

$\mathrm{X}$-ray diagrams of untreated materials of samples $\mathrm{C}$ and $\mathrm{D}$ give a sequence of basal reflections from about $14 \AA$ basal spacing with an additional long spacing reflection of about $29 \AA$ spacing. These patterns, however, differ from those of usual chlorites in showing unusually intense $14 \AA$ reflections as well as in being accompanied by long spacing reflections of about $29 \AA$ spacing. The $d$-values of the mineral are also a little larger than for fresh chlorite.

After K-saturation, distinct changes in the diffraction patterns were observed. The K-saturated material of sample $\mathrm{D}$ gives an integral sequence of reflections from about $24 \AA$ basal spacing. WALKER $(1949,1957)$ and BARSHAD (1954) have shown that vermiculite contracts to about $10 \AA$ and smectite to about $12.4 \AA$ after K-saturation, but chlorites do not, and that, therefore, $\mathrm{K}$ saturation is useful for distinguishing among these $14 \AA$-type minerals. The $24 \AA$ basal spacing of sample $D$ after K-saturation corresponds to the sum of the spacing of $14 \AA$ chlorite and $10 \AA$ vermiculite layers, and the approximately integral series of the reflections suggest a regular alternation of the two mineral layers. This being the case, mineral of sample $\mathrm{D}$ can be identified as an interstratified mineral of chlorite- and vermiculite-like layers. The x-ray diagram of sample $\mathrm{C}$ after $\mathrm{K}$-saturation shows that sample $\mathrm{C}$ is a mixture of chlorite and the interstratified mineral of which the properties are very similar to that of sample D.

Sample D was boiled in $5 \mathrm{~N} \mathrm{HCl}$ for 30 minutes to examine for the presence of kaolin (KoDAMA and OINUMA, 1963). The x-ray diagram of the $\mathrm{HCl}$-treated material, prepared on a glass slide, is shown in Fig. 5. In the diagram, the diffractions from the interstratified mineral disappear, except for the weak diffraction at $14.2 \AA$. The diffractions at 7.3 and $3.56 \AA$, which can be attributed to kaolin, are clearly recognizable. These diffractions reveal the presence of kaolin.

Consequently, the yellowish green flake (sample C) is composed of chlorite and interstratified chlorite/vermiculite, while brownish yellow flake (sample D) is composed mainly of interstratified chlorite/vermiculite with a minor amount of kaolin. Therefore, the change in the color of the chlorite found at the surface of the outcrop of the talc-chlorite vein, corresponds to the alteration of the chlorite to interstratified chlorite/vermiculite and partially to kaolin. The relative proportions of chlorite and interstratified chlorite/vermiculite and of interstratified chlorite/vermiculite and kaolin vary within a grain as well as from grain to grain. On the basis of the mode of occurrence, the interstratified chlorite/vermiculite and kaolin are regarded as weathering products of chlorite. The detailed mineralogical properties of the interstratified chlorite/ vermiculite are investigated in the following section using the samples $\mathrm{A}, \mathrm{B}$, $\mathrm{C}$ and $\mathrm{D}$. 


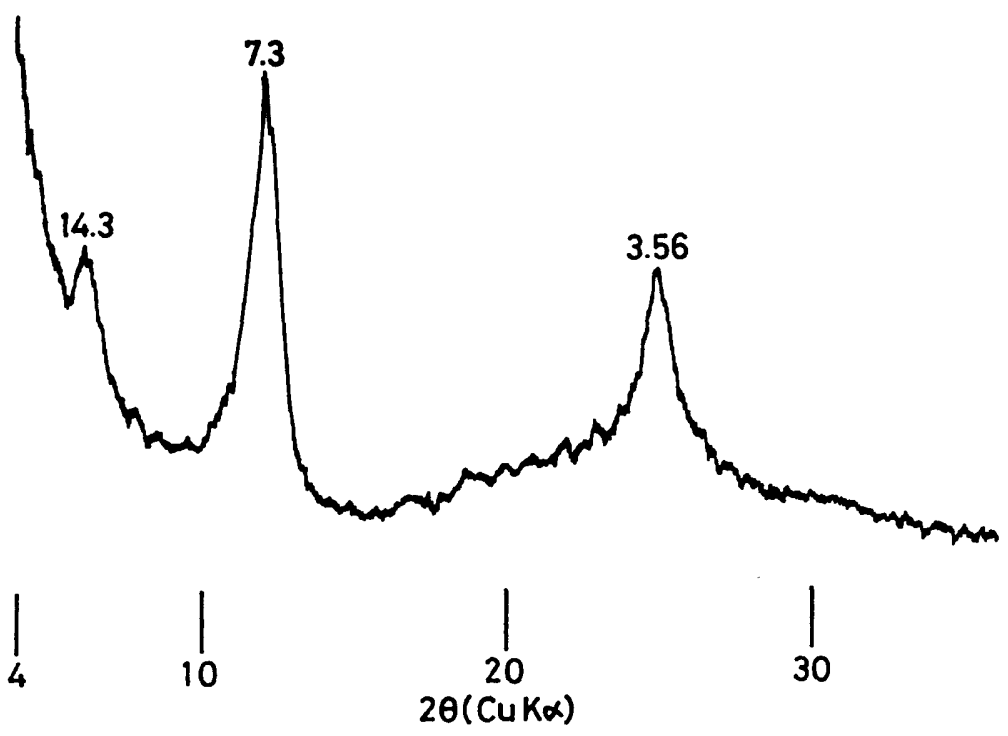

Fig. 5. X-ray powder pattern of sample $\mathrm{D}$ after $\mathrm{HCl}$ treatment.

\section{Mineralogical Examinations of Interstratified Chlorite/Vermiculite}

\section{Chemical Analysis}

The chemical analyses of samples A, B and D were made by EPMA. The analysed points are indicated in Plate 18. Analysed points AF1 and AF2 in sample A and B1, B2 and B3 in sample B are fresh chlorite. Sample B corresponds to the parent material of sample $D$. Judging by their appearance under the microscope, A1 and A2 in sample A correlate with the yellowish green flake of sample $\mathrm{C}$, which is an intimate mixture of chlorite and interstratified chlorite/vermiculite. Sample D is composed mainly of interstratified chlorite/ vermiculite with a minor amount of kaolin. The results of the analyses are shown in Table 4. As for the fresh chlorites, the average compositions of $\mathrm{AF} 1$ and $\mathrm{AF} 2$, and of $\mathrm{B} 1, \mathrm{~B} 2$ and $\mathrm{B} 3$ are shown in the table.

The results of the chemical analyses listed in Table 4 show that the chemical compositions of D1 and D2, which are composed mainly of interstratified chlorite/vermiculite, are markedly different from that of the parent chlorite. D1 and D2 are richer in $\mathrm{SiO}_{2}$ and poorer in $\mathrm{FeO}$ and $\mathrm{MgO}$ than the parent chlorite. They also differ from the parent chlorite in containing a small amount of $\mathrm{CaO}$. $\mathrm{A} 1$ and $\mathrm{A} 2$ show chemical compositions intermediate between that of the parent chlorite and those of D1 and D2. The intermediate chemical compositions of $\mathrm{A} 1$ and $\mathrm{A} 2$ are in agreement with the fact that $\mathrm{A} 1$ and $\mathrm{A} 2$ are a mixture of chlorite and interstratified chlorite/vermiculite. The change in the amount of $\mathrm{Al}_{2} \mathrm{O}_{3}$ from the parent chlorite to $\mathrm{D} 2$ is, however, 
Table 4. Chemical analyses of fresh and weathered chlorites.

\begin{tabular}{l|rrrrrr}
\hline Sample & \multicolumn{1}{c}{ AF } & B & \multicolumn{1}{c}{ A1 } & \multicolumn{1}{c}{ A2 } & \multicolumn{1}{c}{ D1 } & \multicolumn{1}{c}{ D2 } \\
\hline $\mathrm{SiO}_{2}$ & 32.32 & 32.16 & 33.42 & 34.61 & 35.47 & 36.71 \\
$\mathrm{Al}_{2} \mathrm{O}_{3}$ & 13.51 & 14.31 & 13.01 & 13.03 & 14.11 & 15.12 \\
$\mathrm{FeO}$ & 8.32 & 7.94 & 8.09 & 7.33 & 6.88 & 6.74 \\
$\mathrm{MgO}$ & 30.68 & 31.00 & 29.16 & 28.94 & 27.33 & 26.79 \\
$\mathrm{CaO}$ & - & - & $\underline{0.09}$ & $\underline{0.03}$ & $\underline{0.33}$ & $\underline{0.39}$ \\
Total & $\overline{84.83}$ & $\overline{85.41}$ & $\overline{83.77}$ & $\overline{83.94}$ & $\overline{84.12}$ & $\overline{85.75}$ \\
\hline
\end{tabular}

AF, A1, A2: sample A (green flake), having coarse-grained radiated scaly form. The edge of the flake has been altered partially and shows an appearance similar to that of sample $\mathrm{C}$.

B: sample B (green flake), having granular form.

D1, D2: sample D (brownish yellow flake), having granular form.

AF, B: fresh chlorites.

A1, A2, A3: mixtures of chlorite and interstratified chlorite/vermiculite.

D1, D2: interstratified chlorite/vermiculite.

not simple. $\mathrm{Al}_{2} \mathrm{O}_{3}$ content decreases from the parent chlorite to $\mathrm{A} 2$, and increases from A2 to D2. As mentioned above, sample D contains a small amount of kaolin, and the excessive amount of $\mathrm{Al}_{2} \mathrm{O}_{3}$ in $\mathrm{D} 1$ and $\mathrm{D} 2$ is probably due to the presence of kaolin.

These results reveal that the interstratified chlorite/vermiculite has relatively high silica and low magnesia, alumina and iron contents compared with the parent chlorite. The interstratified chlorite/vermiculite has been formed by weathering of chlorite, and such a chemical composition of the mineral suggests the preferential removal of the octahedral cations of chlorite as the main weathering mechanism.

The structural formula of the parent chlorite was calculated on the basis of $\mathrm{O}_{20}(\mathrm{OH})_{16}$. Calculation of the precise structural formula of interstratified chlorite/vermiculite is difficult, since all samples contain varying proportions of chlorite and/or small amounts of kaolin together with the interstratified chlorite/vermiculite. In order to consider the chemical composition of the interstratified chlorite/vermiculite, however, appropriate estimation of the numbers of ions in a unit composed of a 2:1 layer, and hydroxide and hydrous sheets, may be useful. As mentioned above, the chemical analysis of weathered chlorites suggests the preferential removal of octahedral cations of chlorite by weathering. If this is the case, then, the number of ions per unit can be estimated by assuming the same tetrahedral $\mathrm{Si}$ to $\mathrm{Al}$ ratio as for the parent chlorite. The results of this estimation are shown in Table 5 .

The values of $(\mathrm{OH}, \mathrm{O})$ for the weathered chlorites (A1, A2, D1 and D2) were derived from the total charge of cations when iron was in ferrous form. It is, however, reasonable to suppose that some amounts of iron, being in ferrous form in parent chlorite, have been oxidized to $\mathrm{Fe}^{3^{+}}$during the weathering process. As to the oxidation of $\mathrm{Fe}^{2+}$ to $\mathrm{Fe}^{3+}$ ions in the chlorite structure, BRINDLEY (1961) suggested that $\mathrm{OH}^{-}$would be reduced to $\mathrm{O}^{2-}$ in conjunction 
Table 5. Calculation of ions in a unit.

\begin{tabular}{|c|c|c|c|c|c|c|c|}
\hline Sample & & AF & B & A1 & A2 & D1 & D2 \\
\hline \multirow{2}{*}{ Tetrahedral } & $\mathrm{Si}$ & 6.41 & 6.32 & 6.41 & 6.41 & 6.32 & 6.32 \\
\hline & $\mathrm{Al}$ & 1.59 & 1.68 & 1.59 & 1.59 & 1.68 & 1.68 \\
\hline \multirow{7}{*}{ Octahedral } & $\mathrm{Al}$ & 1.57 & 1.64 & 1.35 & 1.25 & 1.28 & 1.39 \\
\hline & $\mathrm{Fe}$ & 1.38 & 1.31 & 1.30 & 1.13 & 1.03 & 0.97 \\
\hline & $\mathrm{Mg}$ & 9.07 & 9.08 & 8.33 & 7.99 & 7.26 & 6.88 \\
\hline & $\mathrm{Ca}$ & - & - & 0.02 & 0.01 & 0.06 & 0.07 \\
\hline & Total & $\overline{12.02}$ & $\overline{12.03}$ & 11.00 & 10.38 & $\overline{9.63}$ & $\overline{9.31}$ \\
\hline & 0 & 20 & 20 & 20 & 20 & 20 & 20 \\
\hline & $(\mathrm{OH}, \mathrm{O})$ & 16 & 16 & 13.76 & 12.42 & 10.86 & 10.33 \\
\hline
\end{tabular}

Ions in a structural unit of fresh chlorite are calculated on the basis of $\mathrm{O}_{20}(\mathrm{OH})_{16}$. Cations in a unit of weathered chlorite are estimated from the calculation by assuming the same tetrahedral $\mathrm{Si}$ to $\mathrm{Al}$ ratio as for the parent chlorite, and the value of $(\mathrm{OH}, \mathrm{O})$ of weathered chlorite is derived from the total charge of cations assuming ferrous iron. AF, B, A1, A2, D1 and D2 are same to those in Table 4.

with the oxidation of $\mathrm{Fe}^{2+}$ to $\mathrm{Fe}^{3+}$, as follows: $\mathrm{Fe}^{2+}(\mathrm{OH})^{-} \rightarrow \mathrm{Fe}^{3+} \mathrm{O}^{2-+}+\mathrm{H}$. Following BRINDLEY's hypothesis, the value of $(\mathrm{OH}, \mathrm{O})$ calculated assuming ferrous iron gives the total number of $\mathrm{OH}^{-}$and $\mathrm{O}^{2-}$ ions, the latter being derived from the reduction of $\mathrm{OH}^{-}$in association with the oxidation of $\mathrm{Fe}^{2+}$ to $\mathrm{Fe}^{3+}$, and it corresponds to the number of sites occupied by $\mathrm{OH}^{-}$ions when the oxidation does not occur.

In the Table 5, the total numbers of octahedral cations in weathered chlorites have smaller values than for the parent chlorite, and the values for D1 and D2, which are composed mainly of interstratified chlorite/vermiculite, are near to that contained in the ideal formula for regularly interstratified chlorite/ vermiculite which contains a total of about 9 cations in its octahedral positions. The values for $(\mathrm{OH}, \mathrm{O})$ in the units of weathered chlorites decrease as the total numbers of cations decrease, and the values for D1 and D2 are also near to that contained in the ideal formula for regularly interstratified chlorite/ vermiculite which contains $10 \mathrm{OH}$ ions.

Each cation of $A 1$ and $A 2$ takes a value intermediate between the parent chlorite and sample $\mathrm{D}$, and these values of $\mathrm{A} 1$ and $\mathrm{A} 2$ are in agreement with the fact that they are a mixture of chlorite and interstratified chlorite/vermiculite.

\section{X-ray Analysis}

In the former section, the interstratified mineral formed by weathering is identified as interstratified chlorite/vermiculite from its x-ray properties after $\mathrm{K}$-saturation. After K-saturation, the interstratified chlorite/vermiculite gives an integral sequence of basal reflections from about $24 \AA$ spacing. In this section, $\mathrm{x}$-ray properties of the interstratified chlorite/vermiculite is further investigated.

Sample $\mathrm{D}$ was saturated with $\mathrm{Mg}$ and $\mathrm{Ca}$ by washing with $1 \mathrm{~N}\left(\mathrm{CH}_{3} \mathrm{COO}\right)_{2} \mathrm{Mg}$ 

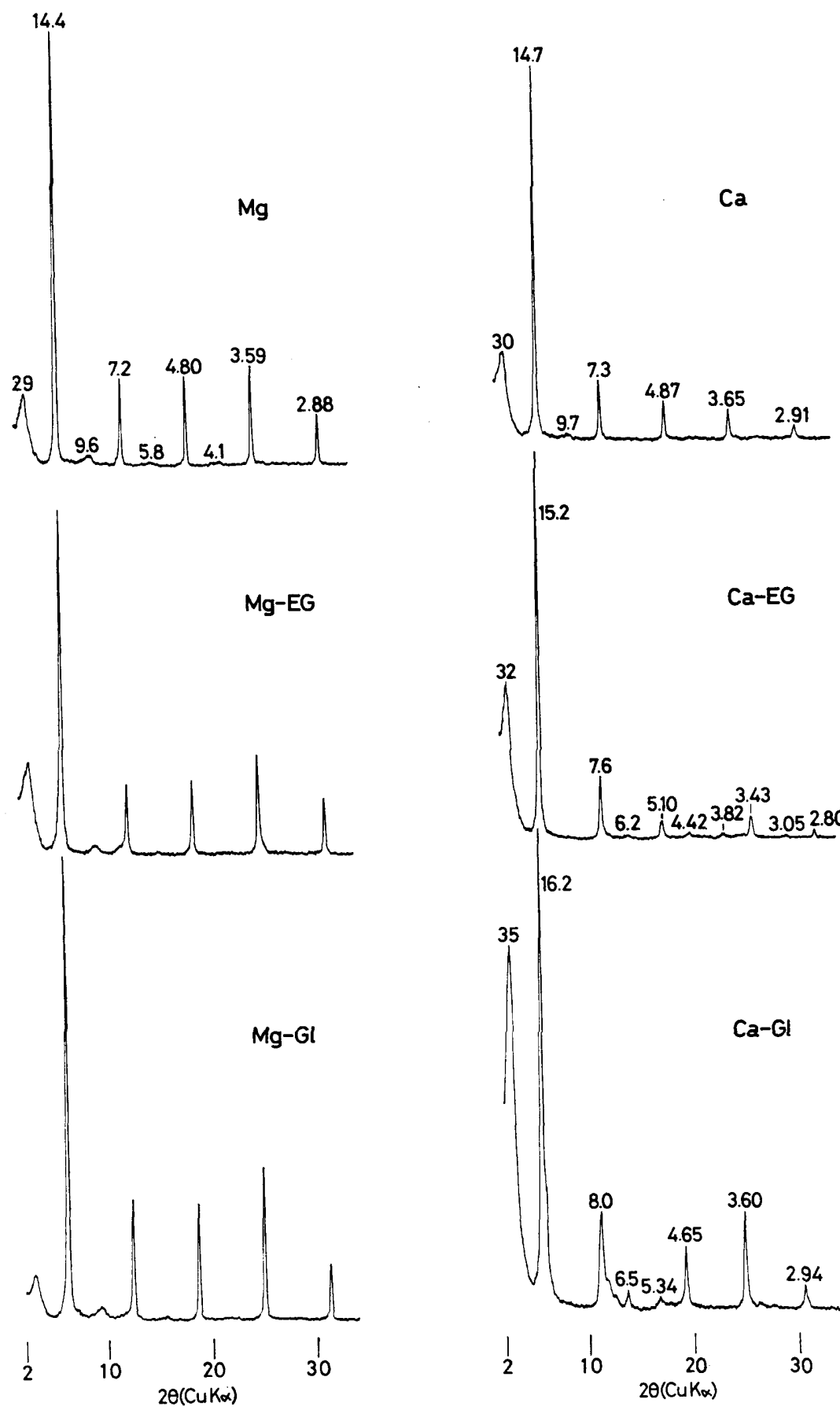

15.2

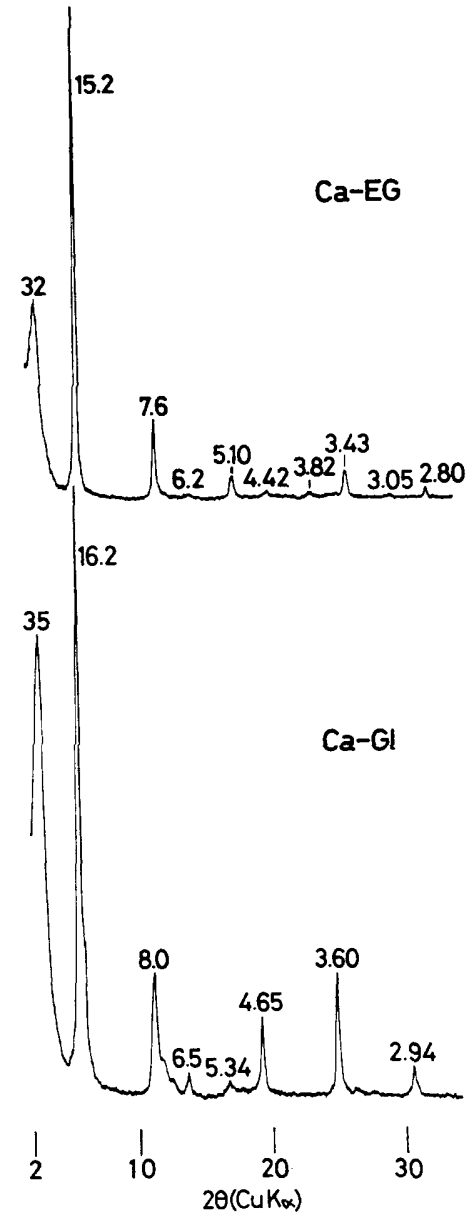

Fig. 6. X-ray patterns of sample D.

Mg: Mg-saturated material.

$\mathrm{Ca}$ : Ca-saturated material.

EG: after ethylene glycol-solvation. Gl: after glycerol-solvation. 
and with $1 \mathrm{~N}\left(\mathrm{CH}_{3} \mathrm{COO}\right)_{2} \mathrm{Ca}$. The $\mathrm{Mg}$ - and $\mathrm{Ca}$ - saturated materials, prepared on glass slides, were treated with ethylene glycol and glycerol, then their x-ray patterns, together with those of untreated materials, were taken using $\mathrm{CuK} \alpha$ radiation (Fig. 6). The $\mathrm{Mg}$-saturated material gives an integral sequence of basal reflections from about $28.8 \AA$ spacing. Ethylene glycol- and glycerolsolvations do not expand the $\mathrm{Mg}$-saturated material. The Ca-saturated material also gives an integral sequence of basal reflections from about $29.2 \AA$ spacing, which is a little larger than that of the Mg-saturated material. Ethylene glycol and glycerol solvations expand the Ca-saturated material, giving spacings of about $30.7 \AA$ after ethylene glycol-solvation and of about $32.4 \AA$ after glycerolsolvation.

In all cases, sample $D$ gives an integral sequence of basal reflections, although its basal spacing varies with the exchangeable cation and the solvent

Table 6. X-ray data for regulary interstratified chlorite/vermiculite and chlorite.

\begin{tabular}{|c|c|c|c|c|c|c|c|c|c|}
\hline \multicolumn{6}{|c|}{ chlorite/vermiculite } & \multicolumn{4}{|c|}{ chlorite } \\
\hline $00 l$ & $d(\AA)$ & $d(001)$ & $\mathrm{I}_{\mathrm{obs}}$ & $\mid \mathbf{F}$ lobs & $F_{\text {calc }}$ & $d(\AA)$ & $\overline{I_{\mathrm{obs}}}$ & $\mid F_{\text {lobs }}$ & $F_{\text {calc }}$ \\
\hline 001 & 29 & 29 & 48.2 & 22.4 & 41.1 & 14.4 & 71.7 & 18.4 & -20.2 \\
\hline 002 & 14.4 & 28.8 & 100 & 64.9 & -87.4 & 7.18 & 100 & 43.8 & 45.1 \\
\hline 003 & 9.56 & 28.7 & 10.2 & 31.1 & 40.0 & 4.78 & 71.7 & 56.3 & 54.2 \\
\hline 004 & 7.21 & 28.8 & 22.5 & 61.8 & 63.1 & 3.581 & 75.2 & 75.9 & 76.4 \\
\hline 005 & 5.76 & 28.8 & 3.53 & 30.7 & 34.6 & 2.863 & 20.6 & 52.0 & -48.1 \\
\hline 006 & 4.79 & 28.7 & 18.3 & 84.6 & 73.7 & 2.384 & 0.41 & 9.0 & -9.3 \\
\hline 007 & 4.12 & 28.8 & 1.88 & 31.7 & 31.1 & 2.043 & 4.21 & 34.5 & 34.6 \\
\hline 008 & 3.59 & 28.7 & 27.0 & 139.3 & 137.1 & 1.787 & 0.171 & 8.2 & -11.7 \\
\hline 009 & 3.20 & 28.8 & 1.03 & 30.9 & 29.9 & 1.588 & 0.596 & 17.7 & -17.2 \\
\hline 0010 & 2.876 & 28.76 & 14.2 & 128.5 & -120.5 & 1. 430 & 2.47 & 40.9 & 41.7 \\
\hline 0011 & - & - & - & - & 15.4 & 1.299 & 0.105 & 9.4 & -9.3 \\
\hline 0012 & 2.396 & 28.75 & 0.278 & 22.0 & -18.3 & 1.191 & 1.23 & 35.3 & 37.4 \\
\hline 0013 & - & - & - & - & 9.6 & - & - & - & 5.2 \\
\hline 0014 & 2.054 & 28.76 & 1.541 & 62.1 & 59.6 & 1. 021 & 0.650 & 27.9 & 29.8 \\
\hline 0015 & - & - & - & - & 5.4 & - & - & - & 0.6 \\
\hline 0016 & 1.799 & 28.78 & 0.257 & 29.9 & -32.4 & 0.8935 & 1.02 & 31.8 & 29.4 \\
\hline 0017 & - & - & - & - & 3.1 & & & & \\
\hline 0018 & 1.598 & 28.76 & 0.171 & 28.2 & -36.3 & & & & \\
\hline 0019 & - & - & - & - & -3.9 & & & & \\
\hline 0020 & 1.438 & 28.76 & 0.881 & 172.5 & 71.1 & & & & \\
\hline 0021 & - & - & - & - & 0.8 & & & & \\
\hline 0022 & 1.307 & 28.75 & $0.090^{7}$ & 0726.1 & -25.3 & & & & \\
\hline 0023 & - & - & - & - & 1.9 & & & & \\
\hline 0024 & 1.198 & 28.76 & 0.349 & 956.0 & 57.5 & & & & \\
\hline 0025 & - & - & - & - & 5.6 & & & & \\
\hline 0026 & - & - & - & - & -2.7 & & & & \\
\hline 0027 & - & - & - & - & 7.4 & & & & \\
\hline 0028 & 1.0264 & 428.74 & 0.146 & $\begin{array}{ll}6 & 39.4\end{array}$ & 46.1 & & & & \\
\hline 0029 & - & - & - & - & 9.7 & & & & \\
\hline 0030 & - & - & - & - & -12.0 & & & & \\
\hline 0031 & - & - & - & - & 10.1 & & & & \\
\hline 0032 & 0.8993 & 328.78 & 0.257 & 48.1 & 47.0 & & & & \\
\hline
\end{tabular}


in the interlayer positions. The integral sequences of basal reflections of the materials after various chemical treatments suggest a regular alternation of two mineral layers. K-saturation of sample D (see Fig. 4) suggests that the two mineral layers are chlorite- and vermiculite-type layers. When a $14.3 \AA$ thickness of the chlorite-type layer is assumed (the measured value for the parent chlorite is $14.30 \AA$ ) the thickness of the vermiculite-type layer would be about $14.5 \AA$ after $\mathrm{Mg}$-saturation, $14.9 \AA$ after Ca-saturation and ethylene glycol-solvation, and $18.1 \AA$ after Ca-saturation and glycol-solvation. These behaviors of the vermiculite-type layer are similar to those of low charge vermiculite (BRINDLEY, 1966), and confirm the identification of sample $D$ as a regularly interstratified chlorite/vermiculite.

$00 l$ reflections from the regularly interstratified chlorite/vermiculite were obtained up to 0032 . Using the $00 \mathrm{l}$ intensites, the one-dimensional structure along $c^{*}$ of the regularly interstratified chlorite/vermiculite was determined. The one-dimensional structure of the parent chlorite was also determined, using the intensities of $00 \mathrm{l}$ reflections up to 0016 from granular chlorite of Zone IV (sample B). The intensities of basal reflections were measured by a diffractometer, using $\mathrm{CuK} \alpha$ radiation for the material prepared on glass slide; the integrated intensity of a reflection was calculated by summing up the heights of the reflection measured at $2 \theta=0.05^{\circ}$ intervals. The x-ray data for the regularly interstratified chlorite/vermiculite and the parent chlorite are shown in Table 6.

A structural model of the regularly interstratified chlorite/vermiculite, having the following composition, was constructed on the basis of the chemical analysis :

chlorite layer: $\quad\left(\mathrm{Mg}_{4.54} \mathrm{Fe}_{0.65} \mathrm{Al}_{0.82}\right)\left(\mathrm{Si}_{3.16} \mathrm{Al}_{0.84}\right) \mathrm{O}_{10}(\mathrm{OH})_{8}$ vermiculite layer: $\left(\mathrm{Al}_{0.64}\right)\left(\mathrm{Mg}_{2.65} \mathrm{~F}_{0.35}\right)\left(\mathrm{Si}_{3.16} \mathrm{Al}_{0.84}\right) \mathrm{O}_{10}(\mathrm{OH})_{2} 4 \mathrm{H}_{2} \mathrm{O}$.

Table 7. Final structures of regularly interstratified chlorite/vermiculite and chlorite.

\begin{tabular}{|c|c|c|c|c|}
\hline & \multicolumn{2}{|c|}{$\begin{array}{c}\text { Chlorite/vermiculite } \\
d(001)=28.76 \AA\end{array}$} & \multicolumn{2}{|c|}{$\begin{array}{c}\text { Chlorite } \\
d(001)=14.30 \AA\end{array}$} \\
\hline & Composition & $\mathrm{Z}$ & Composition & $\mathbf{Z}$ \\
\hline $\begin{array}{l}\text { Interlayer hydroxide } \\
\text { sheet }\end{array}$ & $\begin{array}{l}3.8 \mathrm{Mg}, 0.6 \mathrm{Fe}, 1.6 \mathrm{Al} \\
60 \mathrm{H}\end{array}$ & $\begin{array}{r}0.000 \\
.032\end{array}$ & $\begin{array}{l}3.8 \mathrm{Mg}, 0.6 \mathrm{Fe}, 1.6 \mathrm{Al} \\
6 \mathrm{OH}\end{array}$ & $\begin{array}{r}0.000 \\
.069_{3}\end{array}$ \\
\hline $2: 1$ layer & $\begin{array}{l}6 \mathrm{O} \\
3.2 \mathrm{Si}, 0.8 \mathrm{Al} \\
40,2 \mathrm{OH} \\
5.3 \mathrm{Mg}, 0.7 \mathrm{Fe} \\
4 \mathrm{O}, 2 \mathrm{OH} \\
3.3 \mathrm{Si}, 0.8 \mathrm{Fe} \\
60\end{array}$ & $\begin{array}{l}.134 \\
.154 \\
.214 \\
.250 \\
.286 \\
.345 \\
.364\end{array}$ & $\begin{array}{l}6 \mathrm{O} \\
3.2 \mathrm{Si}, 0.8 \mathrm{Al} \\
4 \mathrm{O}, 2 \mathrm{OH} \\
5.3 \mathrm{Mg}, 0.7 \mathrm{Fe}\end{array}$ & $\begin{array}{l}.268_{b} \\
.308_{6} \\
.424_{b} \\
.5\end{array}$ \\
\hline $\begin{array}{l}\text { Interlayer water } \\
\text { Interlayer cation }\end{array}$ & $\begin{array}{l}4 \mathrm{H}_{2} \mathrm{O} \\
0.6 \mathrm{Al}\end{array}$ & $\begin{array}{l}.460 \\
.5\end{array}$ & & \\
\hline
\end{tabular}




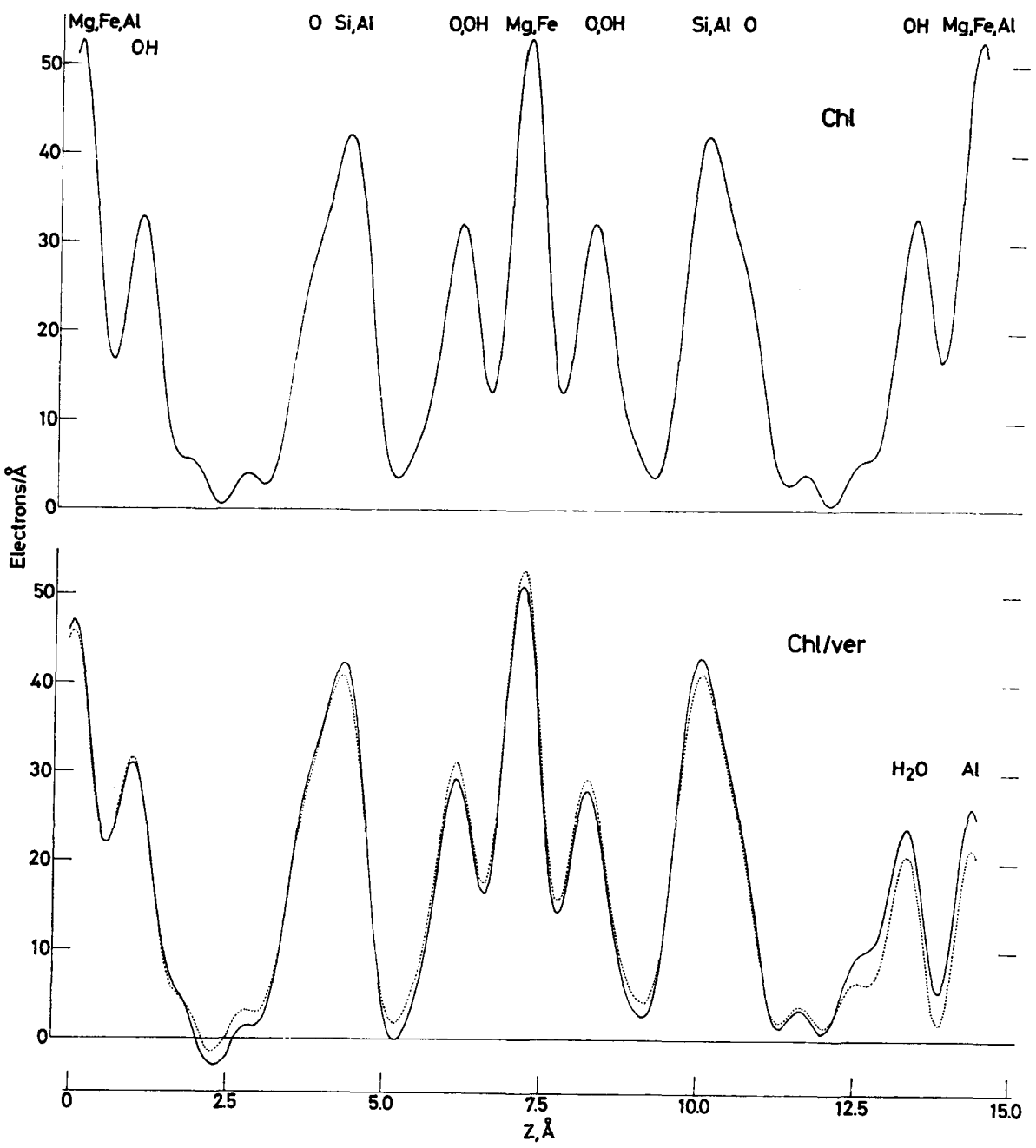

Fig. 7. One-dimensional Fourier syntheses of interstratified chlorite/vermiculite and chlorite. The solid line shows the electron density derived from observed structure factors and the dotted line shows that derived from calculated structure factors of the model.

The structural model was then refined by changing the z-parameters using a least-square procedure. The structure of chlorite was refined by changing the z-parameters and the amounts of octahedral cations in the 2:1 layer and hydroxide sheet using a least-square procedure. The final structures of the interstratified chlorite/vermiculite and of the chlorite are shown in Table 7. The residual $R$ values for the interstratified chlorite/vermiculite and for the chlorite are 10.6 and $4.6 \%$ respectively.

Results of one-dimensional Fourier syntheses of electron densities normal to basal planes of the interstratified chlorite/vermiculite and of the chlorite are shown in Fig. 7. The Fourier projection of the interstratified mineral is similar 

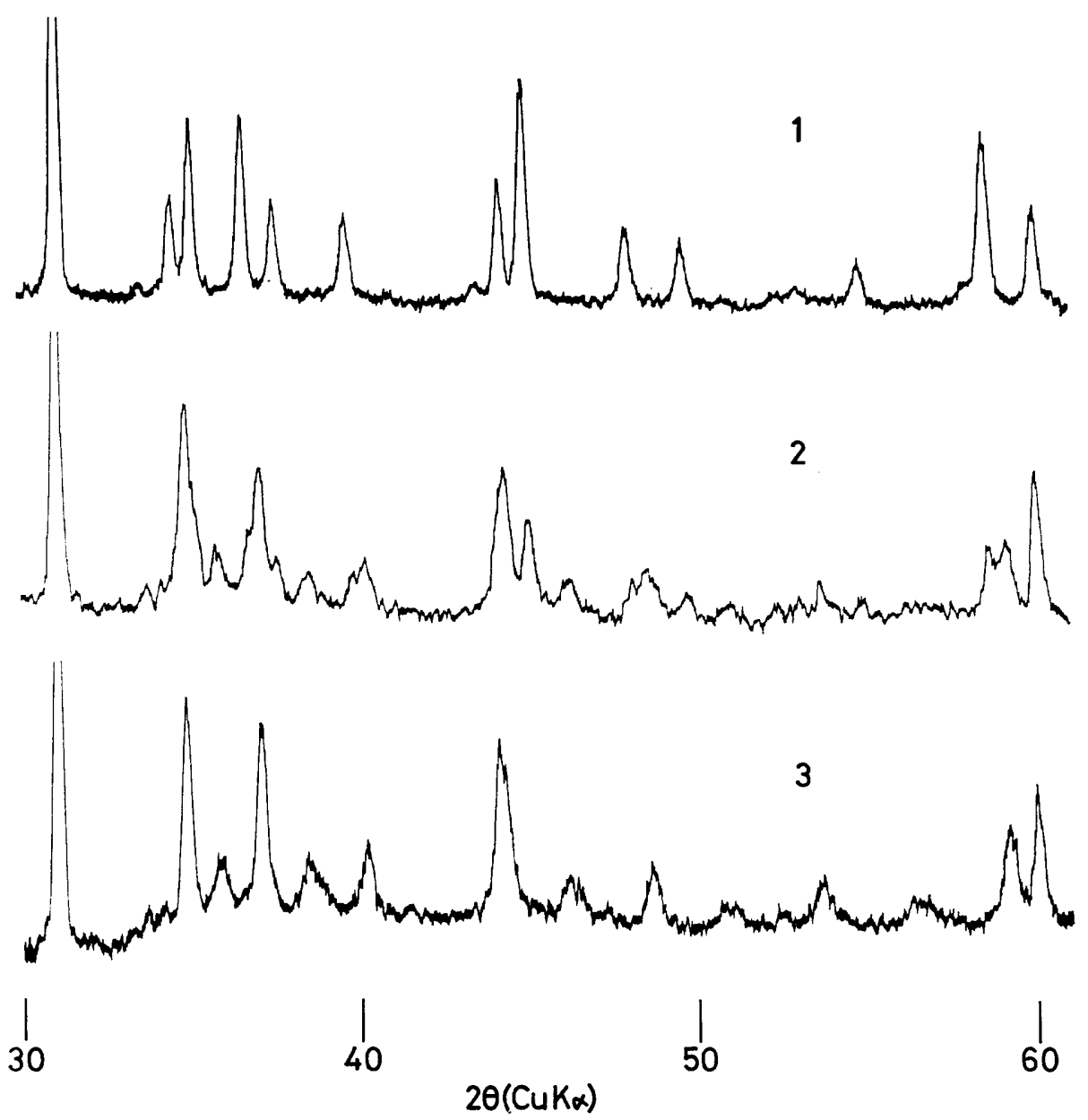

Fig. 8. X-ray diffraction diagrams of random powder samples.
1: sample $B$.
2: sample C.
3: sample D.

to that of its structural model, and shows that the electron densities of the 2:1 layer and hydroxide sheet are similar to that of the parent chlorite, and that the electron density of the cation sheet in the interlayer position of the vermiculite component layer are very low. These results confirm the regular alternation of chlorite- and vermiculite-type layers.

Fig. 8 shows random powder patterns for the parent chlorite (sample B), for sample $\mathrm{C}$, which is a mixture of regularly interstratified chlorite/vermiculite and chlorite, and for sample D, mainly composed of regularly interstratified chlorite/vermiculite.

The powder pattern for sample B agrees with that of the II $b$ polytype of chlorite. Sample D also shows distinct $h k l$ reflections. The pattern of sample D differs, however, from that of sample B, and does not agree with any pattern previously reported for chlorites and vermiculites. Reflections of sample $\mathrm{C}$ are 
Table 8. $20 l$ spacings and intensities of chlorite/vermiculite.

\begin{tabular}{|c|c|c|c|c|c|c|c|}
\hline \multirow{2}{*}{$\begin{array}{l}d_{\text {calc }} \\
2.672\end{array}$} & \multirow{2}{*}{$\begin{array}{l}20 l \\
200\end{array}$} & \multicolumn{2}{|c|}{$\mathrm{I}_{\text {calc }}(\mathrm{II} b / \mathrm{I} a)$} & \multicolumn{2}{|c|}{$\mathrm{I}_{\mathrm{calc}}(\mathrm{II} b / \mathrm{II} a)$} & \multirow{2}{*}{$\frac{d_{\mathrm{obs}}}{-}$} & \multirow{2}{*}{$\frac{\mathrm{I}_{\mathrm{obs}}}{-}$} \\
\hline & & 2 & 0.1 & 2 & 0.1 & & \\
\hline 2.660 & $\begin{array}{l}201 \\
20 \overline{1}\end{array}$ & $\begin{array}{r}2 \\
11\end{array}$ & 0.7 & $\begin{array}{l}2 \\
7\end{array}$ & 0.7 & 2.66 & 0.8 \\
\hline 2.627 & $\begin{array}{l}202 \\
20 \overline{2}\end{array}$ & $\begin{array}{r}3 \\
28\end{array}$ & 1.7 & $\begin{array}{r}3 \\
13\end{array}$ & 1.2 & 2.622 & 0.8 \\
\hline 2.574 & $\begin{array}{l}203 \\
20 \overline{3}\end{array}$ & $\begin{array}{l}56 \\
61\end{array}$ & 6.6 & $\begin{array}{r}26 \\
101\end{array}$ & 9.4 & 2.574 & 10 \\
\hline 2.505 & $\begin{array}{l}204 \\
204\end{array}$ & $\begin{array}{l}15 \\
44\end{array}$ & 3.3 & $\begin{array}{l}44 \\
91\end{array}$ & 10 & 2.505 & 2 \\
\hline 2.424 & $\begin{array}{l}205 \\
20 \overline{5}\end{array}$ & $\begin{array}{r}39 \\
139\end{array}$ & 10 & $\begin{array}{l}11 \\
78\end{array}$ & 6.6 & 2.426 & 8 \\
\hline 2.335 & $\begin{array}{l}206 \\
20 \overline{6}\end{array}$ & $\begin{array}{l}14 \\
46\end{array}$ & 3.4 & $\begin{array}{l}44 \\
16\end{array}$ & 4.4 & 2.338 & 2 \\
\hline 2.241 & 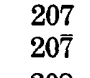 & $\begin{array}{c}0.4 \\
12\end{array}$ & 0.7 & $\begin{array}{r}8 \\
38\end{array}$ & 3.4 & 2.243 & 3 \\
\hline 2.146 & $\begin{array}{l}208 \\
20 \overline{8}\end{array}$ & $\begin{array}{l}2 \\
1.5\end{array}$ & 0.2 & $\begin{array}{r}13 \\
9\end{array}$ & 1.6 & - & - \\
\hline 2.051 & $\begin{array}{l}209 \\
209\end{array}$ & $\begin{array}{r}69 \\
6\end{array}$ & 4.2 & $\begin{array}{c}43 \\
0.4\end{array}$ & 3.2 & 2.049 & 7.5 \\
\hline 1.959 & $\begin{array}{l}2010 \\
20 \overline{1} \overline{0}\end{array}$ & $\begin{array}{l}17 \\
11\end{array}$ & 1.6 & $\begin{array}{r}30 \\
5\end{array}$ & 2.6 & 1.961 & 1.7 \\
\hline 1.871 & $\begin{array}{l}2011 \\
20 \overline{1} \overline{1}\end{array}$ & $\begin{array}{l}3 \\
6\end{array}$ & 0.5 & $\begin{array}{l}1.6 \\
9\end{array}$ & 0.8 & 1.871 & 2.6 \\
\hline 1.786 & $\begin{array}{l}2012 \\
20 \overline{1} 2\end{array}$ & $\begin{array}{r}12 \\
1\end{array}$ & 1.0 & $\begin{array}{l}18 \\
0.9\end{array}$ & 1.4 & 1.792 & 1 \\
\hline 1.706 & $\begin{array}{l}2013 \\
20 \overline{1} \overline{3}\end{array}$ & 16 & 1.1 & $\begin{array}{r}2 \\
17\end{array}$ & 1.4 & 1.707 & 2 \\
\hline 1.631 & $\begin{array}{l}2014 \\
20 \overline{1} \overline{4}\end{array}$ & $\begin{array}{c}6.5 \\
14\end{array}$ & 1.2 & $\begin{array}{r}4 \\
19\end{array}$ & 1.7 & 1.627 & 1 \\
\hline 1.560 & $\begin{array}{l}2015 \\
20 \overline{1} \overline{5}\end{array}$ & $\begin{array}{r}2 \\
48\end{array}$ & 2.8 & $\begin{array}{l}0.6 \\
38\end{array}$ & 2.9 & 1.561 & 4.3 \\
\hline 1.493 & $\begin{array}{l}2016 \\
20 \overline{1} \overline{6}\end{array}$ & $\begin{array}{l}1.4 \\
1.1\end{array}$ & 0.1 & $\begin{array}{l}4 \\
4\end{array}$ & 0.6 & - & - \\
\hline 1.431 & $\begin{array}{l}2017 \\
2017\end{array}$ & $\begin{array}{l}17 \\
0.7\end{array}$ & 1.0 & $\begin{array}{l}26 \\
0.4\end{array}$ & 1.9 & 1.427 & 3 \\
\hline 1.373 & $\begin{array}{l}2018 \\
201 \overline{1}\end{array}$ & $\begin{array}{l}27 \\
0.5\end{array}$ & 1.5 & $\begin{array}{r}18 \\
3\end{array}$ & 1.6 & 1.375 & 1.5 \\
\hline
\end{tabular}

a composite of the patterns of samples $\mathrm{B}$ and $\mathrm{D}$. The $h k l$ reflections from sample D have been inferred to be $20 l(13 l)$ series reflections, which are comon in layer silicates, and can be indexed as listed in Table 8 in termes of an orthohexagonal cell with $b=9.25$ and $c=28.8 \AA$, as was done for the interstratified sericite/sudoite studied by SHIRozU and Higashi (1976).

The one-dimensional Fourier synthesis of the regularly interstratified chlorite/vermiculite reveals that alternate hydroxide sheets of chlorite have been altered preferentially. Thus, if it is assumed that the chlorite component layer maintains II $b$-type layer stacking after weathering, then I $a$ - or II $a$-type layer stacking of the vermiculite component layers is probable for the interstratified mineral, given that it has orthogonal cells. Fig. 9 shows the possible stacking sequences of the chlorite and vermiculite component layers in the (010) pro- 


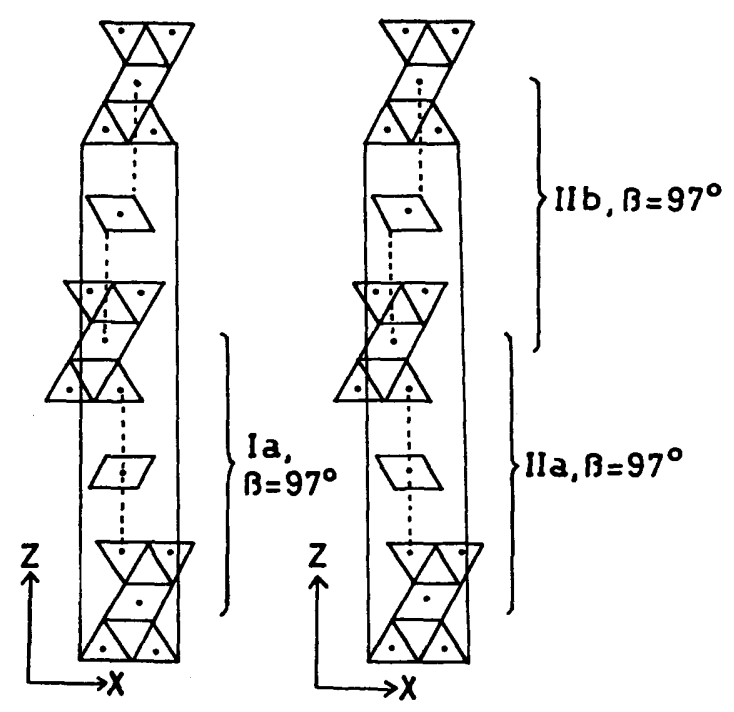

Fig. 9. Possible structural schemes of chlorite/vermiculite in $(010)$ projection.

jection, assuming an orthogonal cell. Intensities of the $20 l$ (13l) reflections have been calculated for these two structures, which have ideal hexagonal nets, with results listed in Table 8. The intensities calculated for a structure having a stacking sequence composed of II $b$ chlorite and I $a$ vermiculite layer types show better agreement with observed intensities.

\section{Infrared Absorption Analysis}

Infrared absorption spectra of regularly interstratified chlorite/vermiculite (sample D) and chlorite (sample B) were recorded with a Jasco Model A-302 grating infrared spectrophotometer, using the $\mathrm{KBr}$ pellet technique, and are shown in Fig. 10.

The pattern of sample B agrees with that of Mg-chlorite (SHIROZU, 1977). The pattern of sample $D$ differs from that of chlorite, especially in the region from 4000 to $1800 \mathrm{~cm}^{-1}$ and from 1200 to $800 \mathrm{~cm}^{-1}$, and absorption due to kaolin is also recognized together with that due to the interstratified mineral. The band at $3420 \mathrm{~cm}^{-1}$ of sample $\mathrm{D}$ is partly due to interlayer water in the vermiculite component layer of regularly interstratified chlorite/vermiculite. The $\mathrm{OH}$ bands due to the hydroxide sheet of the chlorite component layer are overlapped with this band and are obscure. In the lattice vibration region of sample $\mathrm{D}$, the band at $1003 \mathrm{~cm}^{-1}$ is strong, and the shoulders at 1050 and $1085 \mathrm{~cm}^{-1}$, which are distinct in the pattern of chlorite, are obscure in the same way as those of non-interstratified vermiculite. The band at $955 \mathrm{~cm}^{-1}$ is, however, distinct, like that of chlorite. Such a pattern for the regularly interstratified chlorite/vermiculite may suggest that its lattice has in part a vermiculitic character as well as a chloritic one. 


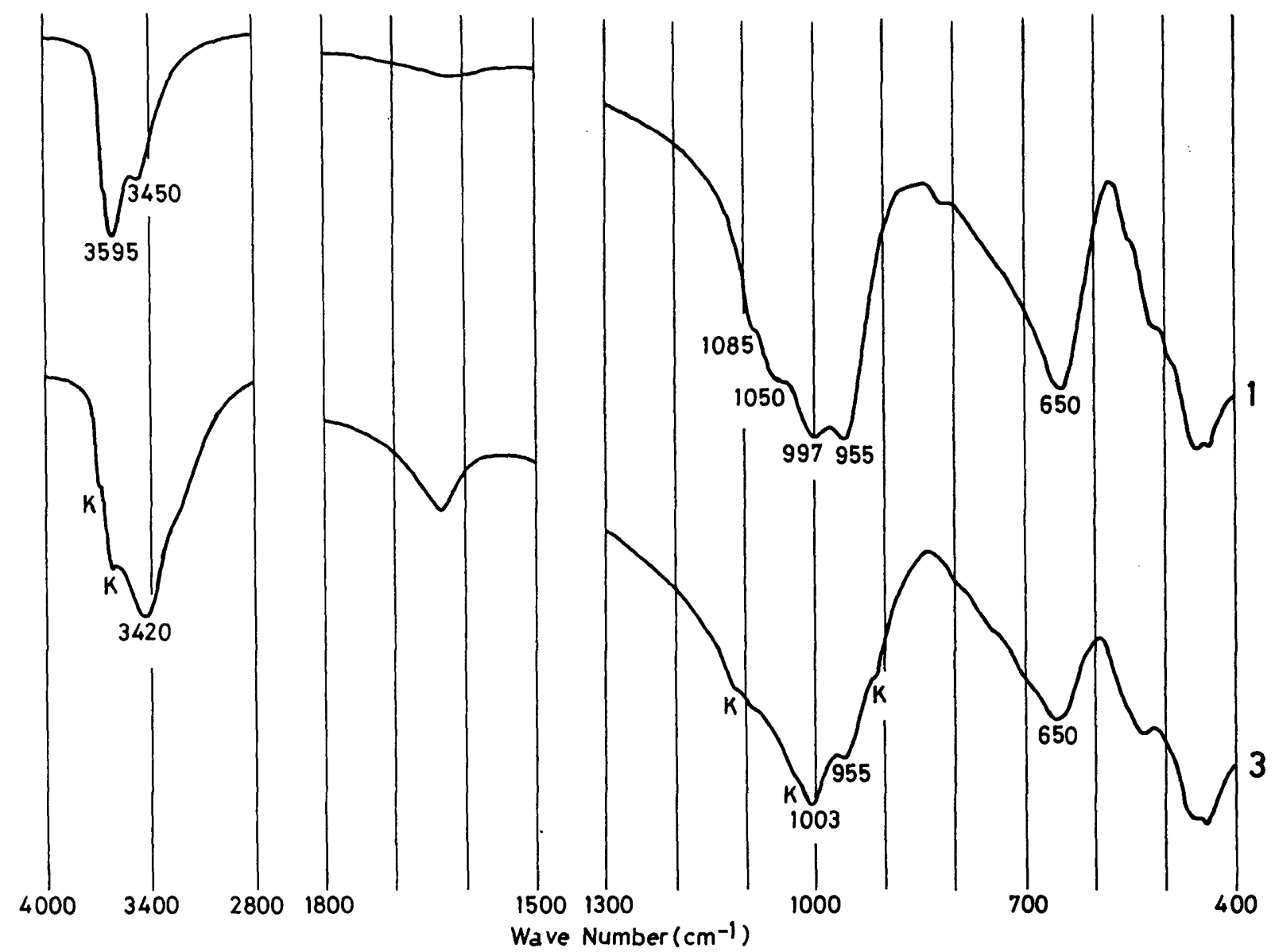

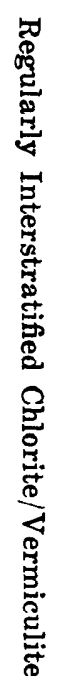

Fig. 10. Infrared absorption spectra af samples $B$ and $D$.

1: sample B. 3 : sample D. $\mathrm{K}$ : absorption due to kaolin. 


\section{Thermal Analysis}

DTA and TG curves for sample B (the parent chlorite) and for sample D (regularly interstratified chlorite/vermiculite) were obtained with a Shimazu simultaneous macro TG-DTA apparatus, using $250 \mathrm{mg}$ material (Fig. 11).

The curves for the parent chlorite agree with those for normal $\mathrm{Mg}$-chlorite, and the endothermic peak at $680^{\circ} \mathrm{C}$ is attributable to dehydroxylation of the interlayer hydroxide sheet, and that at $820^{\circ} \mathrm{C}$ to dehydroxylation of $2: 1$ layer, followed by the formation of new phases (MACKENZIE, 1970). The DTA curve of sample $\mathrm{D}$ shows additional endothermic peaks at $126,172,280$ and $546^{\circ} \mathrm{C}$ associated with the two endothermic peaks at 650 and $823^{\circ} \mathrm{C}$. The temperature $\left(650^{\circ} \mathrm{C}\right)$ of the peak due to interlayer dehydroxylation of the chlorite component
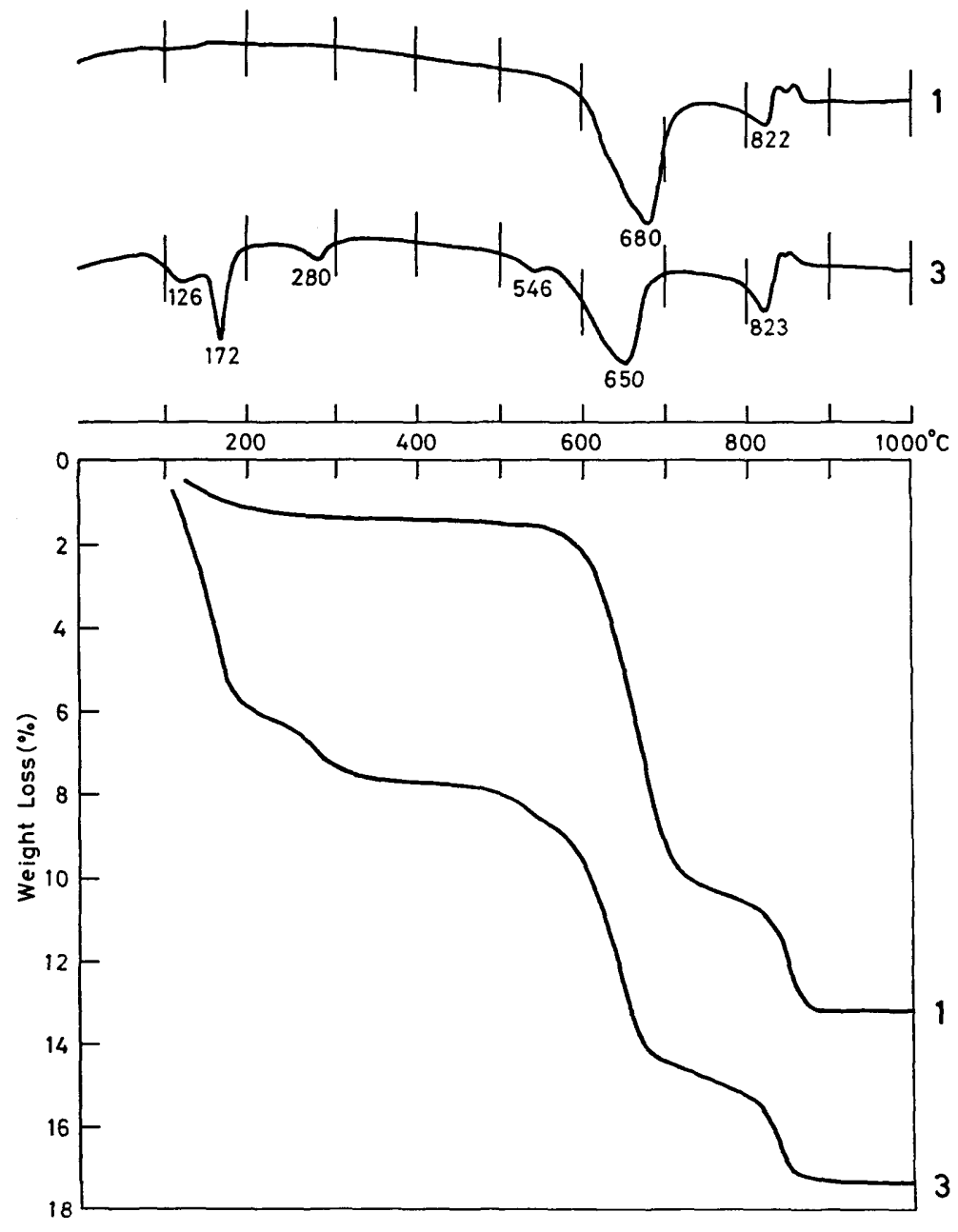

Fig. 11. DTA and TG curves of samples B and D.

1: sample $B . \quad 3$ : sample $D$. 
layer is slightly lower than that of sample B. Three endothermic peaks in the range from 120 to $280^{\circ} \mathrm{C}$ corresponding with weight losses on the TG curves are attributable to dehydration of the interlayer water of the vermiculite component layer. The small endothermic peak at about $550^{\circ} \mathrm{C}$ may be due to kaolin impurity.

\section{Summary and Discussion}

The talc-chlorite vein in the serpentinite body at Torika is mainly composed of talc and chlorite with small amounts of magnetite and carbonate minerals. These minerals occur in symmetrical and zonal arrangement. Thus the vein is divided into five zones based on the mineral assemblage and the crystal habit of chlorite. All the chlorites in the vein are $\mathrm{Mg}$-rich ones with IIb polytype, although the $\mathrm{Al}$ content varies with the zone in which they occur and with their habits. The surface of the outcrop of the vein is contaminated by brown colloidal material mainly composed of goethite, and the chlorite flakes on the surface have changed from green to yellowish green or brownish yellow in color. These yellowish green or brownish yellow flakes contain an interstratified mineral investigated in this study. On the basis of its mode of occurrence, the interstratified mineral is regarded as being formed by the weathering of chlorite.

The mineralogical properties of the interstratified mineral can be summarized as follows:

(1) Based on the x-ray properties of the material after various chemical treatments, the interstratified mineral formed by weathering is identified as regularly interstratified chlorite/vermiculite.

(2) In the weathered chlorite grains, regularly interstratified chlorite/ vermiculite and chlorite form an intimate mixture, and the relative proportions of both the minerals vary within a grain as well as from grain to grain. Kaolin is found in the sample composed mainly of interstratified chlorite/ vermiculite. This suggests that the regularly interstratified chlorite/vermiculite is a relatively stable intermediate phase in the weathering process of chlorite.

(3) These weathered chlorites are richer in $\mathrm{SiO}_{2}$ and poorer in $\mathrm{MgO}, \mathrm{FeO}$ and $\mathrm{Al}_{2} \mathrm{O}_{3}$ than the parent chlorite. The number of ions in a unit composed of a 2:1 layer and hydroxide and hydrous sheets was calculated by assuming the same tetrahedral $\mathrm{Si}$ and $\mathrm{Al}$ ratio as for the parent chlorite. The result reveals that the regularly interstratified chlorite/vermiculite formed by weathering has about 9 octahedral cations and $10 \mathrm{OH}$ ions, which approximates the ideal formula for regularly interstratified chlorite/vermiculite.

(4) One-dimensional Fourier synthesis normal to the basal plane of the interstratified chlorite/vermiculite confirms its regular alternation of chloriteand vermiculite-type layers.

(5) The regularly interstratified chlorite/vermiculite gives $h k l$ reflections, which have been indexed in terms of an orthohexagonal cell ( $a=5.34, b=9.25$ and $c=28.8 \AA$ ). The $20 l$ intensities are interpreted by a stacking sequence composed of I $a$ vermiculite and II $b$ chlorite layer types. 


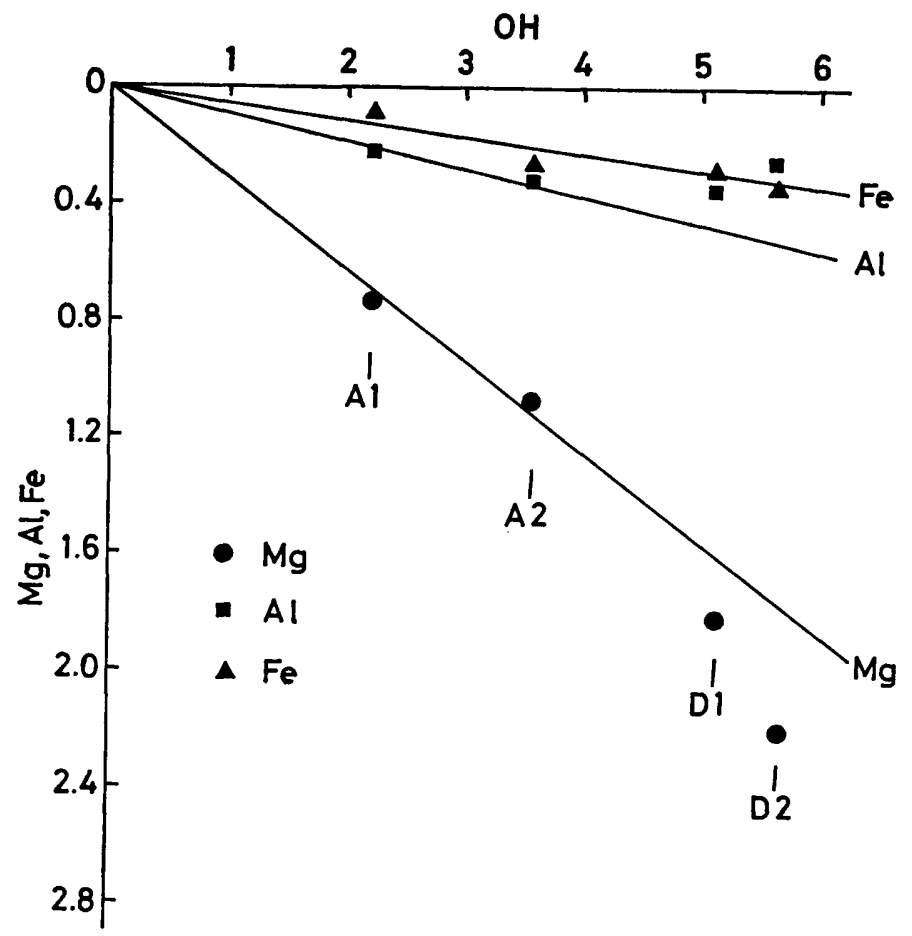

Fig. 12. Relations between the decreases of $\mathrm{Mg}$, $\mathrm{Fe}$ and $\mathrm{Al}$ atoms and $\mathrm{OH}$ ions in the weathered chlorites against parent chlorites.

A1, A2: Analyses of sample A. D1, D2: Analyses of sample D.

The results summarized in (3) and (4) suggest that the alternate hydroxide sheets of chlorite are attacked preferentially by weathering. JoHNSON (1964) described a regularly interstratified chlorite/vermiculite formed by weathering from chlorite in a Highfield channery silt loam soil profile in Adams Country, Pennsylvania. For the change on weathering of the chlorite, he also suggested a preferential leaching of alternate hydroxide sheets of chlorite, based on the $\mathrm{x}$-ray properties of the interstratified mineral. Regarding the change in chemical composition on the weathering of chlorite to regularly interstratified chlorite/ vermiculite, however, little has hitherto been known.

Now, however, it is possible to calculate the decrease in ions in the change from the parent chlorite to weathered chlorite, using the numbers of ions per unit listed in Table 4. As summarized in (2), weathered chlorites are composed mainly of chlorite and regularly interstratified chlorite/vermiculite, and the relative proportions of both minerals vary. Calculations may give suggestions for the change in chemical composition from chlorite to regularly interstratified chlorite/vermiculite. In Fig. 12, a decrease of each cation of weathered chlorite against the parent chlorite is plotted against the decrease of $\mathrm{OH}^{-}$ions. These plots show that from parent chlorite to $\mathrm{A} 2 \mathrm{Mg}, \mathrm{Fe}$ and $\mathrm{Al}$ ions decrease with linear relations to a decrease of $\mathrm{OH}^{-}$ion. These linear relations are also shown 
in Fig. 12 by solid lines, and they suggest that $3.8 \mathrm{Mg}, 0.6 \mathrm{Fe}$ and $1.0 \mathrm{Al}$ ions decrease for each decrease of $120 \mathrm{H}$ ions.

The allocation of cations between the two octahedral sheets of parent chlorite (sample B) was made in former section (p. 268). Based on those results, the composition of sample $\mathrm{AF}$ is:

$$
\begin{array}{ll}
\text { 2:1 layer } & \left(\mathrm{Mg}_{5.27} \mathrm{Fe}_{0.73}\right)\left(\mathrm{Si}_{6.41} \mathrm{Al}_{1.59}\right) \mathrm{O}_{20}(\mathrm{OH})_{4} \\
\text { hydroxide sheet } & \left(\mathrm{Mg}_{3.80} \mathrm{Fe}_{0.65} \mathrm{Al}_{1.57}\right)(\mathrm{OH})_{12} .
\end{array}
$$

The composition of sample $B$ is:

$$
\begin{array}{ll}
2: 1 \text { layer } & \left(\mathrm{Mg}_{5.30} \mathrm{Fe}_{0.70}\right)\left(\mathrm{Si}_{6.32} \mathrm{Al}_{1.68}\right) \mathrm{O}_{20}(\mathrm{OH})_{4} \\
\text { hydroxide sheet } & \left(\mathrm{Mg}_{3.78} \mathrm{Fe}_{0.81} \mathrm{Al}_{1.64}\right)(\mathrm{OH})_{12} .
\end{array}
$$

Both chlorites have similar 2:1 layers and hydroxide sheets. The decreases of $3.8 \mathrm{Mg}$ and $0.6 \mathrm{Fe}$ per $12 \mathrm{OH}$ ions are very similar to those for hydroxide sheets of chlorite. A decrease of $1.0 \mathrm{Al}$ per $120 \mathrm{H}$ ions is, however, less than the $1.6 \mathrm{Al}$ content per $12 \mathrm{OH}$ of the hydroxide sheet of the parent chlorite. The 2:1 layers of both parent chlorites have a similar negative charge of about -1.6 , and the negative charge is electrostatically balanced by the positive charge of hydroxide sheet. When the hydroxide sheet of chlorite has decomposed, some cations must be retained in the interlayer position to balance the negative charge of the 2:1 layer. When the retained cation is an $\mathrm{Al}$ ion, $1.6 / 3 \mathrm{Al}$ ions are necessary in the interlayer position to balance the negative charge of 2:1 layer. The solid line for $\mathrm{Al}$ in Fig. 12 shows a decrease of $1.0 \mathrm{Al}$ per $12 \mathrm{OH}$ ion, then the sum of the retained and decreased $\mathrm{Al}$ ions is about 1.5, i.e. 1.6/3+1.0. This amount (1.5 Al) is similar to the $1.6 \mathrm{Al}$ content of the hydroxide sheet of parent chlorite.

For D1 and D2, the decreases of $\mathrm{Mg}$ and $\mathrm{Al}$ ions are plotted at slightly different positions from the solid lines in Fig. 12, e.g., the decrease of $\mathrm{Mg}$ per that of $\mathrm{OH}$ ions is larger and the decrease of $\mathrm{Al}$ ions is smaller than those expected on the basis of the decreases in A1 and A2. In sample D, a small amount of kaolin is intermixed with the interstratified chlorite/vermiculite. These deviations from the linear relations found in A1 and A2 may be due to the kaolin.

Consequently, it is reasonable to suppose that the plots of weathered chlorites, shown in Fig. 12, indicate that the dominant compositional change from chlorite to regularly interstratified chlorite/vermiculite can be attributed to the alteration of the hydroxide sheet to a hydrous sheet with $\mathrm{Al}$ ions as exchangeable cations.

The result summarized in (5) suggests that the vermiculite component layer has I $a$-type stacking. The I $a$ layer sequence is common in non-interstratified vermiculite. HAYES (1970) suggested that vermiculite resulting from the weathering of II $b$ chlorite has a I $a$-type layer sequence, but he stated that the $h 0 l$ reflections of the regularly interstratified chlorite/vermiculite resulting from the weathering of II $b$ chlorite could not be related to any particular chlorite polytype. The I $a$-type stacking of the vermiculite component layer suggested in the present study is consistent with these results, and furthermore indicates that in this interstratified mineral there is a kind of three dimensional regu- 
larlity of a type similar to the semirandom stacking of BRowN and BAILEY (1962).

\section{Acknowledgements}

The author wishes to express his sincere gratitude to Prof. Haruo Shirozu of Kyushu University for valuable suggestions in the course of this work. Special acknowledgements are due to Assoc. Prof. Yoshikazu Aoki, Dr. Takashi Watanabe and Prof. Fumitoshi Hirowatari of Kyushu University who gave the author much instructive advice. He would like to record his hearty thanks to Mrs. Hidemi Akamine for electron microprobe analyses, to Dr. Shoji Higashi of Kochi University and Dr. Hideo Akasako of the New Energy Development Organization for permission to use their computer programs.

\section{References}

BARShAD, I. (1954): Cation exchange in micaceous minerals: II. Replaceability of ammonium and potassium from vermiculite, biotite, and montmorillonite. Soil Sci., 78, 57-76.

Bayliss, P. and Loughnan, F. C. (1964): Mineralogical transformations accompanying the chemical weathering of clay-slates from New South Wales. Clay Min. Bull., 5, 353-362.

BRINdey, G. W. (1961): The X-ray Identification and Crystal Structures of Clay Minerals. (G. Brown ed.), Miner. Soc., London, 251-260.

(1966): Ethylene glycol and glycerol complexes of smectites and vermiculites. Clay Minerals, 6, 237-259.

Brown, B. E. and Balley, S. W. (1962): Chlorite polytypism: I. Regular and semirandom one-layer structures. Amer. Mineral., 47, 819-850.

Droste, J. B. (1956) : Alteration of clay minerals by weathering in Wisconsin tills. Bull. Geol. Soc. Amer., 67, 911-918.

- - Bhattacharya, N. and Sunderman, J. A. (1962): Clay mineral alteration in some Indiana soils. Clays and Clay Min. Proc. 9th Natl. Conf., 329-342.

Harbillon, A. J. and MAKUMbi, M. N. (1975): Weathering of chlorite in a soil derived from a chlorite schist under humid tropical conditions. Geodarma, 13, 89-104.

Harrison, J. L. and MURRAY, H. H. (1959) : Clay mineral stability and formation during weathering. Clays and Clay Min. Proc. 6th Natl. Conf., 144-153.

Hayes, J. B. (1970): Polytypism of chlorite in sedimentary rocks. Clays and Clay Min., 18, 285-306.

JACKSON, M. L. (1963): Interlayering of expansible silicates in soils by chemical weathering. Clays and Clay Min., 11, 29-46.

JoHnson, L. J. (1964) : Occurrence of regularly interstratified chlorite-vermiculite as a weathering product of chlorite in a soil. Amer. Mineral., 49, 556-572.

KoDAmA, H. and OINUmA, K. (1963) : Identification of kaolin minerals in the presence of chlorite by x-ray diffraction and infrared absorption spectra. Clays and Clay Min. Proc. 11th Natl. Conf., 236-249.

Mackenzie, R. C. (1970): Differential Thermal Analysis (D. M. C. Mackenzie ed.), Academic Press, 497-537.

Millot, G. and CAMEz, T. (1963): Genesis of vermiculite and mixed-layered vermiculite in the evolution of the soils of France. Clays and Clay Min. Proc. 10th Natl. Conf., 90-95.

NodA, M. and MUtA, K. (1957): The geological structure of the Nishisonogi Peninsula, 
Nagasaki Prefecture. Rep. Ear. Sci. Dept. Gen. Edu. Kyushu Univ., 4, 17-21. (in Japanese)

Post, J. L. and JANke, N. C. (1974) : Properties of 'swelling' chlorite in some Mesozoic formations of California. Clays and Clay Min., 22, 67-77.

SHIRozU, H. (1958) : X-ray powder patterns and cell dimensions of some chlorites in Japan, with a note on their interference colors. Min. Jour., 2, 209-223.

(1960): Determination of the chemical composition of chlorites by x-ray and optical methods. Jour. Japan. Assoc. Min. Petr. Econ. Geol., 44, 18-22. (in Japanese)

(1977): Infrared spectra of chlorites. Min. Soc. Japan, 1977 Annual Meeting Abstracts, 105. (in Japanese)

- and HigAshr, S. (1976) : Structural investigations of sudoite and regularly interstratified sericite/sudoite. Min. Jour., 8, 158-170.

WALKER, G. F. (1949): Distinction of vermiculite, chlorite and montmorillonite in clays. Nature, 164, 577-578.

(1957): On the differentiation of vermiculites and smectites in clays. Clay Min. Bull., 3, 154-163.

(1961): The X-ray Identification and Crystal Structures of Clay Minerals (G. Brown ed.), Miner. Soc., London, 317-318.

Winchell, A. N. (1951) : Elements of Optical Mineralogy: Part II. Descriptions of Minerals. John Wiley and Sons, Inc., New York, 381-389. 